\title{
INSOLVENCIAS PUNIBLES Y LEY CONCURSAL
}

\author{
Fernando Gómez Martín \\ Auditor y Censor Jurado de Cuentas. Profesor de Derecho Concursal \\ Universidad de Deusto-Bilbao
}

\begin{abstract}
Sumario: 1. Insolvencias punibles en el Código Penal de 1995. 2. Doctrina científica. 2.1. Alzamiento de bienes. 2.2. Alzamiento en procesos concursales. 2.3. Delitos concursales. 2.4. Falsedad contable en procesos concursales. 3. Doctrina del Tribunal Supremo. 3.1. Alzamiento de bienes en perjuicio de acreedores (art. 257.1.1. ${ }^{\circ}$ ). 3.2. Actos de disposición patrimonial o generadores de obligaciones obstativos al embargo de bienes (art. 257.1.2. ${ }^{\circ}$ ). 3.3. Actos de disposición de bienes o para contraer obligaciones con la finalidad de eludir responsabilidades civiles ex delicto (art. 258). 3.4. Favorecimiento de acreedores (art. 259). 3.5. Insolvencia causada o agravada por el deudor (art. 260). 3.6. Falsedad contable (art. 261). 4. Incumplimiento de deberes contables. 5. Autoría y complicidad. 6. Calificación civil y proceso penal. 7. El Ministerio Fiscal. 8. Concurso de delitos. 9. Prescripción.
\end{abstract}

Me propongo relacionar las insolvencias punibles con el nuevo concurso de acreedores, regulado en la Ley 22/2003, de 9 de julio, desde la perspectiva contable y financiera, pues su contenido económico es evidente. Para ello, dedicaré la atención al Código Penal de 1995, aprobado por Ley Orgánica núm. 10/1995, de 23 de noviembre, y vigente desde el 24 de mayo de 1996, sin olvidar la modificación de la Ley Orgánica 10/1995, de 23 de noviembre, por Ley Orgánica 15/2003, de 25 noviembre, que da nueva redacción a los artículos 259, 260 y 261, para tipificar los delitos de favorecimiento de acreedores, de insolvencia causada o agravada por el deudor y de falsedad contable, respectivamente, en sede concursal.

Cuando el deudor, declarado en concurso, estuviere legalmente obligado a llevar contabilidad (art. 6.3 de la Ley concursal), es decir, si fuese sujeto contable ${ }^{1}$, será necesaria la revisión de registros y do-

1 El concepto de sujeto contable se utiliza con profusión en el Real Decreto 296/2004, de 20 de febrero, por el que se aprueba el régimen simplificado de la contabilidad, aunque ya se mencionó en la Disposición final primera Real Decreto 1815/91, de 20 de diciembre, por el que se aprueban las Normas para la formulación de cuentas anuales consolidadas. 
cumentos contables ex art. 75.1.2..$^{\circ}$ de la citada Ley, cuya función verificadora se encomienda a la administración concursal, quien podrá apoyarse en auxiliares delegados, si el juez los nombra, y servirá como medio de prueba para la denuncia, entre otros, de los hechos tipificados en el capítulo VII del Título XIII del Libro II del vigente Código Penal.

A la luz de la jurisprudencia y de la doctrina científica consultada, trataré de exponer mi punto de vista, desde la vertiente contable, económica y financiera, con el propósito de destacar su relación con la contabilidad, en la medida que puede servir de apoyo, como medio de prueba, en el esclarecimiento de los tipos regulados en los arts. 257 a 261 del vigente Código Penal.

\section{Insolvencias punibles en el Código Penal de 1995}

En los arts. 259 a 261 se trata de proteger el proceso concursal y se pretende impedir maquinaciones del deudor con los acreedores, para evitar que el deudor defraude a éstos o a los órganos auxiliares de Juez.

El bien jurídico protegido, en el delito de insolvencia, se halla constituido por los derechos de los acreedores a la satisfacción de sus créditos con el patrimonio del deudor, y el contenido del injusto radicará, por tanto, en el peligro o en el daño que tales derechos puedan sufrir a consecuencia de la causación de insolvencia por parte del deudor. Se identifica la insolvencia como estado de hecho, donde el importe de las obligaciones exigibles supera al de los bienes y derechos realizables, y se distingue de la falta de liquidez, para concluir que la cesación en los pagos será el medio normal de manifestación de la insolvencia, aunque no la demostración suficiente, pues un deudor solvente puede dejar de pagar sus obligaciones vencidas.

Conviene detenerse, previamente, en el concepto de insolvencia, desde la óptica mercantil y financiera, que no coincide con el concepto penal, al exigirse, en esta sede, la imposibilidad total o parcial de hacer frente a las obligaciones y que la insolvencia haya sido causada o agravada dolosamente por el deudor para perjudicar a sus acreedores. Las menciones a la insolvencia, en los arts. 258 y 260.1, parece que contemplan situaciones de déficit patrimonial (activo real inferior al pasivo exigible), que determina la insolvencia en el nuevo concurso (art. 2.2: deudor que no puede cumplir regularmente sus obligaciones exigibles). En cuanto al concepto de crisis económica empresarial, que se contempla como antesala de la insolvencia, con 
causas diversas internas o externas, puede relacionarse con la disminución o ausencia de beneficios o, incluso, que se incurra en pérdidas, y como consecuencia directa se produce desequilibrio financiero, que provoca iliquidez y dificulta o impide el cumplimiento de las obligaciones de pago.

Ramos Rubio 2 , después de aclarar que el mencionado Capítulo VII del Título XIII del Libro II del nuevo Código Penal castiga sólo los incumplimientos maliciosos, en ningún caso los incumplimientos debidos a causa fortuita o a la imprudencia o negligencia del deudor, define la insolvencia como la situación o estado de desequilibrio del patrimonio del deudor, cuyos valores realizables no alcanzan a cubrir las prestaciones exigibles, desequilibrio del que se deriva la imposibilidad definitiva de que los acreedores puedan ver satisfechos en su totalidad sus derechos de crédito. Respecto a si los delitos de insolvencia son delitos contra el patrimonio o contra el orden socioeconómico, se inclina por aceptar que el legislador del nuevo $\mathrm{CP}$, ante la evidencia de que en la mayoría de los delitos que agrupa el Título XIII del Libro II coexisten un atentado a bienes individuales (el patrimonio de la víctima) junto a otro contra bienes colectivos (el orden socioeconómico), se ha visto superado por la dificultad de desentrañar cuál es el predominante en cada caso y ha dejado a jueces y tribunales la tarea de resolver el problema.

Ferrer Barriendos ${ }^{3}$ estima que el enunciado general de lo que el Anteproyecto de Ley Concursal de 1983 llama «concurso culpable» ha inspirado la nueva regulación de la insolvencia punible en el Código Penal, como categoría única contrapuesta al concurso fortuito, y que es, en esencia, el delito de insolvencia punible tipificado en el art. 260 del CP. Las referencias a «causación o agravación» y la introducción de un concepto jurídico-penal indefinido, como el de «crisis económica», revelan las fuentes donde ha bebido el precepto penal, es decir, en la reforma concursal.

Como he anticipado, la Ley Orgánica 15/2003, de 25 noviembre, dedica el artículo único a la modificación de la Ley Orgánica 10/1995, de 23 de noviembre (RCL $1995 \backslash 3170$ y RCL 1996, 777), del Código Penal y, en relación con las insolvencias punibles, se modifican los artículos siguientes:

2 Ramos Rubio, Carlos, «Las insolvencias punibles en el Código Penal de 1995». Partida Doble, núm. 69, julio-agosto 1996, págs. 25-38.

${ }^{3}$ Ferrer Barriendos, Agustín, «Repercusiones concursales en el nuevo Código Penal», en Derecho Concursal II (Cuadernos de Derecho Judicial). Madrid, Consejo General del Poder Judicial, 1996, págs. 582-583. 
Octogésimo noveno. Se modifica el artículo 259, que queda redactado como sigue:

«Será castigado con la pena de uno a cuatro años de prisión y multa de 12 a 24 meses, el deudor que, una vez admitida a trámite la solicitud de concurso, sin estar autorizado para ello ni judicialmente ni por los administradores concursales, y fuera de los casos permitidos por la Ley, realice cualquier acto de disposición patrimonial o generador de obligaciones, destinado a pagar a uno o varios acreedores, privilegiados o no, con posposición del resto».

Nonagésimo. Se modifica el artículo 260, que queda redactado como sigue:

«1. El que fuere declarado en concurso será castigado con la pena de prisión de dos a seis años y multa de ocho a 24 meses, cuando la situación de crisis económica o la insolvencia sea causada o agravada dolosamente por el deudor o persona que actúe en su nombre. 2. Se tendrá en cuenta para graduar la pena la cuantía del perjuicio inferido a los acreedores, su número y condición económica. 3. Este delito y los delitos singulares relacionados con él, cometidos por el deudor o persona que haya actuado en su nombre, podrán perseguirse sin esperar a la conclusión del proceso civil y sin perjuicio de la continuación de éste. El importe de la responsabilidad civil derivada de dichos delitos deberá incorporarse, en su caso, a la masa. 4. En ningún caso, la calificación de la insolvencia en el proceso civil vincula a la jurisdicción penal».

Nonagésimo primero. Se modifica el artículo 261, que queda redactado como sigue:

«El que en procedimiento concursal presentare, a sabiendas, datos falsos relativos al estado contable, con el fin de lograr indebidamente la declaración de aquél, será castigado con la pena de prisión de uno a dos años y multa de seis a doce meses».

Disposición final quinta.

«La presente Ley Orgánica entrará en vigor el día 1 de octubre de 2004, con excepción de la disposición final primera, la disposición final segunda, la disposición final tercera y la disposición final cuarta, que entrarán en vigor el día siguiente al de la publicación de esta Ley Orgánica en el Boletín Oficial del Estado, y de los apartados octogésimo octavo, octogésimo noveno y nonagésimo del artículo único, que modifican los artículos 259, 260 y 261 del Código Penal, que entrarán en vigor el mismo día en que lo haga la Ley 22/2003, de 9 de julio, Concursal» [1 de septiembre de 2004]. 


\section{Doctrina científica}

Vives Antón y González Cussac ${ }^{4}$ ofrecen una amplia visión sobre las insolvencias punibles, así como la obra dirigida por Quintero Olivares $^{5}$ y la de Muñoz Conde 6 . Otros autores, a los que aludiré oportunamente, han publicado sus estudios sobre esta materia.

Las aportaciones doctrinales permiten deducir que el Código Penal de 1995 comporta una profunda transformación en la regulación de la insolvencia punible, que ya no se incluye dentro de las defraudaciones, sino en un título independiente, dedicado a los delitos contra el patrimonio y contra el orden socioeconómico, en el que quedan las insolvencias como la nota común de los alzamientos y concursos, de tal forma que las insolvencias son el género, mientras que alzamientos y concursos son especies del mismo. Se delimita, con mayor precisión, la intervención punitiva, relegando al ámbito del Derecho privado los supuestos en que la pena es innecesaria, reformulando algunos tipos preexistentes, creando nuevos y suprimiendo otros. Este giro político-criminal se traduce en una mayor autonomía del Derecho Penal, al fijarse sus propios presupuestos materiales y de orden procesal, es decir, se abandona la norma penal en blanco y se desvincula del proceso civil (al parecer relativamente, según veremos), desapareciendo toda distinción entre sujetos que sean comerciantes o no lo sean.

La insolvencia se clasifica en dos tipos: contable (insuficiencia o incapacidad patrimonial) y aparente (ocultación de bienes), aunque la insolvencia contable no se considera verdadera insolvencia, es decir, que insolvencia no es igual a activo inferior al pasivo exigible (desbalance), pues los valores realizables del activo pueden resultar superiores a las obligaciones pendientes de cumplimiento. Otra categoría de insolvencia se vincula con el alzamiento de bienes, que entraña un contradictio in terminis, pues si el deudor puede hacer frente a sus obligaciones con el patrimonio realizable, no hay insolvencia, y, si no puede, sí la hay.

Garberí Llobregat ${ }^{7}$ estudia la clasificación de los delitos en atención a sus condiciones de perseguibilidad y distingue: delitos públicos,

4 Vives Antón, T.S. y González Cussac, J.L., Comentarios al Código Penal de 1995. Valencia, Tirant lo Blanch, 1996, vol. II, págs. 1272-1303.

5 Quintero Olivares, Gonzalo y otros, Comentarios al nuevo Código Penal. Pamplona, Aranzadi, 1996, págs. 1174-1194.

${ }^{6}$ Muñoz Conde, Francisco. Derecho Penal-Parte especial. 11.a ed., Valencia, Tirant lo Blanch, 1996, págs. 406-411.

7 Garberí Llobregat, José, «Derecho penal de la empresa (delitos económicos + delitos societarios): aspectos procesales». Actualidad Jurídica Aranzadi, núm. 345, año VIII, 4 de junio de 1998, págs. 1-4. 
privados y semipúblicos (o, si se prefiere, semiprivados). De su lectura parece deducirse que los encuadrados en el Capítulo VII del Título XIII, dedicado a las insolvencias punibles, son delitos públicos y, consecuentemente, su persecución resulta inexcusable, con independencia de la particular voluntad de vindicta o de «retribución» del sujeto pasivo. Esto permite que el Ministerio Fiscal pueda y deba ejercitar la acción penal e instar la incoación del correspondiente proceso penal, en el cual podrán comparecer los acreedores en calidad de «acusadores particulares», espontáneamente o previo el oportuno ofrecimiento de acciones, e incluso cualquier ciudadano en ejercicio de la acción popular. Más frecuente será que los administradores concursales formulen denuncia o deduzcan la correspondiente querella, en las que intervendrá la representación del Ministerio Público.

Maza Martín ${ }^{8}$ considera:

«...aun cuando... el nuevo Código ha consagrado la independencia sistemática de las insolvencias punibles respecto de las figuras clásicas de defraudación (estafa y apropiación indebida, esencialmente), nos movemos en el ámbito de las defraudaciones, en las que, obligadamente, cierta forma de engaño ha de estar presente, aunque no desempeñe el papel rector de la acción que ostenta en la estafa, como ejemplo prototípico de conducta punible defraudatoria».

Después de tratar sobre el concepto civil y mercantil de la insolvencia, se detiene en la insolvencia punible, que

«adjetiva una mera situación, correspondiente a la esfera de las relaciones crediticias, para identificar ciertos supuestos de conductas que desembocan en aquélla, pero incluyendo elementos intencionales y de otro tipo que, haciéndolas reprochables, llegan incluso... a desnaturalizar, en el ámbito de lo penal, aquel concepto inicial, restringiéndolo, en algunas ocasiones, tanto como excediéndolo, en otras.... es una insolvencia a la que se llega a causa (importancia de la relación de causalidad) de una concreta conducta fraudulenta del deudor y, a partir de la vigencia del nuevo Código Penal, siempre intencionada en este sentido... la distorsión del concepto "civil" de la insolvencia, que se opera a la hora de su significación para el Derecho Penal, no sólo restringe aquél, reduciéndolo estrictamente a la insuficiencia patrimonial provocada (o agravada) voluntariamente en fraude del acreedor, sino que, en sentido inverso, también se extiende a supuestos de la que se conoce como "insolvencia aparente", es decir, a la que no es real, sino que tan sólo supone la sustracción ficticia de bienes del patrimonio del deudor,

8 Maza Martín, José Manuel, «Las insolvencias punibles», en Empresa y Derecho Penal (I). Madrid, Consejo General del Poder Judicial (Cuadernos de Derecho Judicial), 1999, págs. 271-272- 273-280-281-283-286. 
mediante actos fiduciarios, para provocar una mera apariencia de imposibilidad para la satisfacción de la deuda, cuando, en realidad, el deudor cuenta con bienes suficientes para ello».

Analiza, seguidamente, las novedades del CP de 1995, entre las que destaca

«un cambio de criterio legislativo de primer orden, es el de la desvinculación de la norma penal respecto de la civil y mercantil, en esta materia... Sin que ello, por supuesto, pueda hacernos creer que esa desvinculación va más allá de los puntos que la propia reforma operada explicita, pues, obviamente, la necesidad de análisis de los aspectos civiles, mercantiles, etc., del soporte fáctico del delito, seguirá, aún de forma substancialmente distinta en muchos extremos, estando presente... Otra innovación de una trascendencia muy superior de la que, a primera vista, pudiera apreciarse, es la de la extensión del ámbito de estos delitos, en lo que a los créditos impagados se refiere... En efecto, hasta hoy se venía entendiendo que la figura del alzamiento de bienes sólo resultaba de aplicación para el caso de insolvencia ante la obligación de hacer frente a créditos de carácter privado. Por lo que quedaban fuera de la protección que este tipo delictivo pudiera dispensar tanto las obligaciones de pago derivadas de la imposición de una sanción (penal o administrativa), cuanto las tributarias o aquellas otras existentes frente a la Seguridad Social, por ejemplo... Y ya, como última novedad relevante digna de ser reseñada... lo dispuesto en el inciso segundo del apartado 2 del art. 260, cuando dice que "El importe de la responsabilidad civil derivada de dichos delitos deberá incorporarse, en su caso, a la masa”, que viene a prescribir, normativamente, lo que, en la práctica, ya era en tantas ocasiones realidad».

\subsection{Alzamiento de bienes}

Presentan destacado interés los delitos tipificados en los citados arts. 257 y 258 , relativos al alzamiento de bienes en perjuicio de acreedores (delitos de peligro, según la doctrina mayoritaria ${ }^{9}$, aunque no faltan autores que lo encasillan como delito de resultado), dada su relevancia en la antesala del concurso de acreedores, pese a que estos tipos penales no se encuentren vinculados directamente a los procesos concursales, salvo la mención del art. 257.3: «3. Este delito será perseguido aun cuando tras su comisión se iniciara una ejecución concursal». Si concurre esta circunstancia, podrá reputarse concurso culpable ex art. 164.2.4. ${ }^{\circ}$ de la Ley Concursal. Respecto de la modalidad de alzamiento regulada en el art. 519 del anterior CP, en el vigente se tipifican

9 Maza Martín, José Manuel, op. cit., págs. 290-291. GonZÁlez CusSAC, José Luis, Los delitos de quiebra, Valencia, Tirant lo Blanch, 2000, pág. 28. 
dos nuevas conductas: el alzamiento procesal o procedimental del art. 257.1.2. ${ }^{\circ} \mathrm{y}$ el alzamiento para eludir la responsabilidad civil derivada del delito, regulada en el art. 258 del CP.

Bueren ${ }^{10}$ matiza que la equiparación actual, tanto para el comerciante como para el no comerciante, conlleva una sanción más severa del alzamiento de bienes y ya no tiene relevancia alguna quién es el acreedor ni cuál es el origen o la naturaleza de la deuda cuyo pago se trata de eludir. Se trata de un delito de lesión, no de peligro, y exige dolo directo, por lo que queda fuera el dolo eventual ${ }^{11}$. Así se declara en el Fundamento de Derecho Primero de la sentencia de la AP de Valencia, de 13.01.1999.

Según Muñoz Conde ${ }^{12}$ :

«El alzamiento de bienes, al igual que las demás insolvencias punibles, en principio, es una infracción patrimonial. En él se da esa doble vertiente de "lucro propio y detrimento ajeno", característica de las infracciones patrimoniales de enriquecimiento. La referencia expresa a los “acreedores" en el núm. 1 del apartado 1 del art. 257 demuestra que son los derechos de éstos, el objeto directo de protección en este delito. Es el patrimonio, pues, el bien jurídico protegido en el delito de alzamiento de bienes, y más concretamente "el patrimonio de los acreedores"...

Por lo que respecta a las conductas castigadas como alzamiento de bienes, en el art. 257 del Código Penal, cabe distinguir tres supuestos que pueden afectar a distintos bienes jurídicos:

- Enajenar u ocultar bienes, antes de que los acreedores hayan entablado ningún procedimiento de ejecución contra ellos.

- Enajenar u ocultar bienes, una vez que se haya entablado por los acreedores un procedimiento de ejecución contra ellos.

- Enajenar u ocultar bienes, una vez pronunciada sentencia firme de ejecución contra ellos, o éstos estuvieran ya embargados o puestos bajo su custodia en depósito...

Todo lo dicho en relación con los anteriores supuestos, también es aplicable, por tanto, a todos los casos de responsabilidades civiles provenientes de delito, que ahora prevé expresamente el art. 258...».

10 BuERen Roncero, Carlos, «Insolvencias punibles». II Jornadas Nacionales sobre el Derecho Concursal. Centro de Estudios Superiores Jurídico-Empresariales. Madrid, 25 de marzo de 1998, pág. 4.

11 Para que concurra ha de darse la conjunción de dos elementos: a) Que el sujeto activo prevea como altamente probable que de su conducta pueda derivarse un resultado antijurídico (elemento intelectual del dolo); y, b) Que, ello no obstante, aun sin querer directamente causar dicho resultado, al menos lo acepte en su fuero interno (elemento volitivo).

12 MuÑoz Conde, Francisco, «El bien jurídico protegido en el delito de alzamiento de bienes», en Empresa y Derecho Penal (II). Madrid, Consejo General del Poder Judicial (Cuadernos de Derecho Judicial), 1999, págs. 232-264. 
Dado que los tipos penales ex art. 257 pueden perseguirse desvinculados de los procedimientos concursales, cuando fueren descubiertos después de iniciarse un proceso concursal, se cuestiona si la administración concursal viene obligada a denunciar la posible existencia de alzamiento de bienes por el deudor, al conocer hechos causantes de este presunto delito, en el ejercicio de sus funciones de verificación patrimonial (masa activa). Estimo que la respuesta será afirmativa, pero $¿$ ante el juzgado de primera instancia al que sirven o en el juzgado de instrucción? La prudencia aconseja ponerlo en conocimiento del juez que dirige el concurso, en solicitud de que acuerde su traslado al Ministerio Fiscal o deduzca testimonio para el Juzgado de Instrucción, por si procediese la apertura de causa penal contra el responsable. En efecto, los artículos 259 y ss. de la LECr. regulan la denuncia, que es una obligación de cualquier ciudadano (salvo alguna excepción) y, especialmente, en aquellos que por sus cargos, profesiones u oficios tuvieran noticia de algún delito público, hasta el punto de que el incumplimiento de la obligación deriva en sanción. La formalización de la misma puede hacerse ante cualquier clase de autoridad (policía, fiscal, juez de guardia o juez civil), sin que tenga especial transcendencia o interés para el denunciante, por cuanto que es un problema de competencia funcional o territorial, que en nada afecta al mismo y, en todo caso, la autoridad receptora de la denuncia trasladará la misma a quien fuera competente.

Los órganos auxiliares del procedimiento concursal mercantil, es decir, la administración concursal, deben comprobar el cumplimiento de la legislación contable y verificar las cuentas anuales o estados financieros intermedios, de cuya función revisora pueden deducir si se han ocultado, hecho desaparecer o transmitido a terceros bienes propios del deudor, con la finalidad de no satisfacer los derechos de los acreedores. En definitiva, pueden investigar si se ha producido segregación de bienes del patrimonio del deudor, cuyo resultado es que el acreedor ha sido privado de las garantías de su crédito y el deudor conserva su patrimonio, aunque ocultándolo.

Bueren ${ }^{13}$ estudia el delito de alzamiento en sus distintas modalidades:

«La conducta típica descrita en el art. 257-1.1. ${ }^{\circ}$ CP consiste en alzarse con sus bienes en perjuicio de los propios acreedores. De lo anterior se desprende la exigencia de cuatro elementos: una relación jurídica obligacional, un ánimo defraudatorio, una modalidad de conducta y un resultado de insolvencia».

13 Bueren Roncero, Carlos, op. cit., págs. 8-10. 
Uría Fernández ${ }^{14}$ aborda, entre otras cuestiones, el concurso del delito de alzamiento de bienes ex art. $257 \mathrm{CP}$ con otras insolvencias punibles, así como el alzamiento ex art. 258 respecto de los créditos tributarios y su devengo.

\subsection{Alzamiento en procesos concursales}

El art. 259 del CP sanciona el supuesto de realización de cualquier acto de disposición patrimonial o generador de obligaciones para favorecimiento de acreedores o anticipación de pagos, como se ha venido denominando en la doctrina y jurisprudencia, con posposición de otros.

Se trata de un delito que exige el requisito de que el producto obtenido (del acto de disposición patrimonial o generador de obligaciones) se haya destinado a pagar a uno o varios acreedores, preferentes o no, con posposición del resto. La excepción sobre casos permitidos por la ley puede ser causa de desorientación, pues desconozco ley alguna que permita tales actos sin autorización judicial y, si existiera, no encuentro sentido a su mención expresa, pues parece más seguro que quien obra legalmente no incurre en delito. He pensado en los acreedores con derecho de ejecución separada, aunque la Ley concursal restringe el tradicional derecho de ejecución separada ex art. 55, con la excepción del art. 76.3 (titulares de créditos con privilegio sobre buques y aeronaves), así como en los actos previstos en el art. 40.715, cuando la administración concursal los haya convalidado o confirmado. La doctrina consultada considera que forma parte de la descripción del tipo y quiere decir que es un elemento que debe ser probado, lo que se lleva a cabo, sin esfuerzo, ante la sola ausencia de norma legal que permita lo que el tipo penal castiga. Ahora bien, al estar integrado en el tipo quiere decir que sería atípica la acción descrita cuando «sea permitido por la ley». El legislador quizá haya querido referirse a supuestos de bienes inembargables, personalísimos, parafernales de la esposa del concursado, etc.

14 URía FernándeZ, Francisco, «La protección penal de los derechos de crédito de la Hacienda Pública: el delito de alzamiento de bienes ¿Novedades en el Código Penal de 1995?», Crónica Tributaria, núm. 80/1996, págs. 115-131.

15 «Los actos del deudor que infrinjan las limitaciones establecidas en este artículo [autorización de la administración concursal, caso de intervención, o sustitución por la misma, en supuestos de suspensión] sólo podrán ser anulados a instancia de la administración concursal y cuando ésta no los hubiese convalidado o confirmado». 
González Cussac ${ }^{16}$ observa:

«... si se acepta que el bien jurídico protegido es el derecho de los acreedores a la satisfacción de sus créditos de conformidad a la preferencia establecida, ha de aceptarse la posibilidad de la responsabilidad criminal del acreedor beneficiado, a título de partícipe. Siempre que, naturalmente, exista inducción, cooperación necesaria, o complicidad, lo que implica conocimiento de la situación concursal y de la preferencia de pago, y voluntad de infringirla en beneficio propio».

Añade:

«... cabe la posibilidad que la autoridad judicial o los órganos del proceso universal [administradores concursales] otorguen una autorización ilícita al deudor, para que anticipe el pago a ciertos acreedores y en perjuicio del resto. En estos casos, hay que distinguir tres grandes grupos de supuestos. Uno primero en el que incluiríamos hipótesis donde no existe acuerdo, pacto o consilium fraudis con el deudor ni con los acreedores beneficiados. El segundo, donde efectivamente se demostrara la existencia de una confabulación entre el juez o los órganos auxiliares y los acreedores privilegiados. Y tercero, cuando en el acuerdo hubiera intervenido el deudor y los garantes del proceso universal. En ninguno de los dos primeros casos podrá aplicarse nunca alguno de los delitos comprendidos en el Capítulo VII, incluido el artículo 259. La razón es muy sencilla: sin la intervención del deudor no puede existir autor, y consiguientemente tampoco podrá haber hecho principal (insolvencia). En realidad el deudor efectúa el pago con la autorización del juez o de los órganos, luego nunca podrá darse el tipo del artículo 259, pues concurre un elemento negativo del mismo. Y tampoco actuará el deudor con ánimo de perjudicar a los demás acreedores, pues más bien actúa "engañado" o cuanto menos de buena fe. Descartado en ambos casos la apreciación de un delito de insolvencia, queda por averiguar si pueden responder penalmente en calidad de otros títulos. En efecto, al margen de la anulación de los acuerdos ilícitos y de la restitución del orden jurídico, los jueces podrían responder como autores de delitos de prevaricación, dolosa o imprudente (arts. 446 y siguientes); cohecho (arts. 419 y siguientes); o malversación de caudales públicos (arts. 432 y siguientes). Si ha existido acuerdo con los acreedores beneficiados, además del posible delito de cohecho, podrían responder en calidad de partícipes en el delito especial de funcionario. Siempre naturalmente han de considerarse las reglas generales del error. En el caso que sean los órganos auxiliares los que tomen el acuerdo ilícito, sin participación judicial, y con independencia del

16 GonZÁlez Cussac, José Luis, «Insolvencias punibles», en Suspensión de pagos, quiebra e insolvencias punibles: doctrina, jurisprudencia y formularios, Juan Hernández Martí (coordinador). Valencia, Tirant lo Blanch, 2001, vol. III, págs. 2117-2120. 
acuerdo con los acreedores beneficiados, se plantea el problema acerca de su condición de funcionarios públicos. Si la respuesta fuera positiva, incluso podrían responder por prevaricación de autoridad o funcionario (art. 404) y también por cohecho (arts. 419 y siguientes). Y si la conducta se calificara de apropiación indebida sería de aplicación el artículo 438... Pero si no se considera funcionarios a los órganos auxiliares, que es la interpretación dominante y probablemente la más correcta, podrían ser castigados por el tipo común de apropiación indebida (art. 252) o de malversación de caudales de conformidad a lo expresamente dispuesto para estas personas en el artículo $435.3 .^{\circ} \ldots$ El tercer grupo de casos, es el que más nos interesa, pues abarca los supuestos donde el juez o los órganos auxiliares, de acuerdo con el deudor, y probablemente con los acreedores beneficiados, autorizan ilícitamente el anticipo de pagos. Aquí lo determinante es constatar la existencia de un auténtico comportamiento de autor por parte del deudor. Si así se constata, nada impedirá considerar al juez o a los órganos auxiliares como partícipes, bien sea a título de inducción o de cooperación necesaria. Más difícil resulta pensar en la responsabilidad a título de complicidad simple, pues es obvio que sin la ilícita autorización del juez o de los órganos auxiliares, no se hubiera podido cometer de este modo el delito. Además, tendrá que considerase si la actuación de éstos puede integrar algunos de los delitos de funcionarios, falsedades, o apropiación indebida antes referidos. Por lo que se refiere a los acreedores privilegiados, si ha existido acuerdo con el deudor y los garantes de la par conditio creditorum, nada impide su responsabilidad por cualquiera de los títulos de partícipe. Por último, ha de advertirse que para que exista participación criminal en el delito del artículo 259, desde luego tendrá que estar admitida a trámite la solicitud de concurso. De modo que aquí existe una nueva condición temporal que afecta tanto a los autores como a los partícipes. Por eso se ha dicho que basta con la admisión a trámite, aunque esté recurrida, si luego se confirma (Ocaña Rodríguez)».

Se tipifica el alzamiento singular en los procedimientos de ejecución colectiva, según Conde-Pumpido ${ }^{17}$, como tutela de la pars conditio creditorum, y estudia la responsabilidad civil de estos delitos de alzamiento, para poner de manifiesto que la obligación cuyo pago se elude es preexistente y mantiene su eficacia tras la ejecución del delito, por lo que reconocer su existencia y condenar en vía penal a una indemnización, cuyo importe fuera el valor de la prestación de la obligación impagada, nada agregaría al statu quo ante. Por ello, lo único que puede hacer desaparecer las consecuencias del delito es el reponer la

17 Conde-Pumpido Ferreiro, Cándido, «Las insolvencias punibles en el nuevo Código Penal». Ponencia presentada en las Jornadas sobre Responsabilidades en el nuevo Código Penal. Delitos societarios, organizadas por Eurotraining. Madrid, 26 y 27 de noviembre de 1996. 
situación patrimonial del deudor al momento previo al alzamiento de bienes, a través de la nulidad de los negocios jurídicos realizados como mecanismos fraudulentos, para que los bienes afectos a la responsabilidad patrimonial sean los existentes en aquel momento. Se destaca que aunque el alzamiento se debata en sede penal, tiene naturaleza civil, por lo que rigen los principios del ordenamiento jurídico privado, para la nulidad del acto o negocio jurídico que fue el mecanismo del alzamiento de bienes, a saber: a) principios dispositivos y de rogación; b) respecto a los derechos de terceros de buena fe, que tendrán derecho a ser oídos. Sólo cabe la nulidad cuando todas las partes intervinientes estén confabuladas (consilium fraudis). Este delito de alzamiento singular (favorecimiento de acreedores o anticipación de pagos) puede dar lugar a la existencia de cómplices, que el nuevo Código Penal, en su art. 28, considera también autores, por su cooperación necesaria para la ejecución con un acto sin el cual el delito no se hubiera efectuado.

Alonso ${ }^{18}$ destaca que, en el caso de los cómplices, se produce en el nuevo Código Penal una agravación de la situación respecto de la anterior, pues en el anterior el cómplice era castigado con una pena inferior a un grado al autor, y el nuevo Código Penal, en su art. 28, considera también autores a los que cooperan a su ejecución con un acto sin el cual no se habría efectuado, siendo evidente, por tanto, que el acreedor que celebra un concierto particular con el deudor en los supuestos previstos en el art. 259, tiene la condición de autor, por cuanto sin él no es posible la comisión del delito, y, en consecuencia, será también reo del delito previsto en ese artículo y recibirá la misma pena que el deudor. Por este motivo, el nuevo Código Penal no dedica, como el antiguo, una regulación especial a los cómplices, en la medida en que su conducta se encuentra perfectamente inmersa en la prevista para el concurso (art. 166 de la Ley Concursal).

La expresión «...una vez admitida a trámite la solicitud de concurso...», resolución que solamente se pronuncia en caso de concurso necesario, según el art. $15^{19}$ de la Ley Concursal, no en el voluntario, puede llevar a confusión, debido a que la estructura del tipo parece querer exigir que los actos de disposición que castiga deben ser cometidos teniendo el deudor conocimiento de la pendencia de un procedimiento de concurso y, por tanto, cuando le sea notificada su declaración (arts. 14.1 y 21.5 de la Ley Concursal).

18 Alonso, José M. ${ }^{\text {a }}$, «Las insolvencias punibles», Revista Dirección y Progreso-APD, núm. 146, julio 1996, pág. 113.

19 «1. Cuando la solicitud hubiera sido presentada por cualquier legitimado distinto al deudor, el juez dictará auto admitiéndola a trámite...» 
El descubrimiento y denuncia de este ilícito penal corresponde, en particular, a la administración concursal, consecuencia de sus funciones de verificación (arts. $40^{20}, 43^{21}, 45^{22}, 71^{23}$ y $82^{24}$ de la Ley Concursal).

\subsection{Delitos concursales}

El art. 260 sanciona el fraude en las situaciones de insolvencia concursal, es decir, cuando la crisis económica o la insolvencia sea causada o agravada dolosamente por el deudor o persona que actúe en su nombre. Se trata de un delito de resultado, que requiere el perjuicio a los acreedores y no es un delito de enriquecimiento. Delito de lesión, por tanto, y no de peligro. Delito doloso que excluye la imprudencia.

Ferrer Barriendos ${ }^{25}$ considera que el elemento objetivo del tipo presupone la previa declaración judicial y no basta, por tanto, que se dé

$20 \ll 1$. En caso de concurso voluntario, el deudor conservará las facultades de administración y disposición sobre su patrimonio, quedando sometido el ejercicio de éstas a la intervención de los administradores concursales, mediante su autorización o conformidad. 2. En caso de concurso necesario, se suspenderá el ejercicio por el deudor de las facultades de administración y disposición sobre su patrimonio, siendo sustituido por los administradores concursales...».

21 «Conservación y administración de la masa activa. 1. En el ejercicio de las facultades de administración y disposición sobre la masa activa, se atenderá a su conservación del modo más conveniente para los intereses del concurso. A tal fin, los administradores concursales podrán solicitar del juzgado el auxilio que estimen necesario. 2. Hasta la aprobación judicial del convenio o la apertura de la liquidación, no se podrán enajenar o gravar los bienes y derechos que integran la masa activa sin autorización del juez. 3. Se exceptúan de lo dispuesto en el apartado anterior los actos de disposición inherentes a la continuación de la actividad profesional o empresarial del deudor, en los términos establecidos en el artículo siguiente».

22 «Libros y documentos del deudor. 1. El deudor pondrá a disposición de la administración concursal los libros de llevanza obligatoria y cualesquiera otros libros, documentos y registros relativos a los aspectos patrimoniales de su actividad profesional o empresarial. 2. A solicitud de la administración concursal, el juez acordará las medidas que estime necesarias para la efectividad de lo dispuesto en el apartado anterior».

23 «1. Declarado el concurso, serán rescindibles los actos perjudiciales para la masa activa realizados por el deudor dentro de los dos años anteriores a la fecha de la declaración, aunque no hubiere existido intención fraudulenta».

24 «1. La administración concursal elaborará a la mayor brevedad posible un inventario que contendrá la relación y el avalúo de los bienes y derechos del deudor integrados en la masa activa a la fecha de cierre, que será el día anterior al de emisión de su informe. En caso de concurso de persona casada en régimen de gananciales o cualquier otro de comunidad de bienes, se incluirán en el inventario la relación y el avalúo de los bienes y derechos privativos del deudor concursado, así como las de los bienes y derechos gananciales o comunes, con expresa indicación de su carácter».

25 Ferrer Barriendos, Agustín, op. cit., pág. 552. 
una situación económica de insolvencia, sino que requiere el estado jurídico de insolvencia, que determina su declaración.

Según Bueren Roncero ${ }^{26}$, para que la conducta típica del art. 260.1 quede configurada se requiere que la actuación se haya llevado a cabo dolosamente, englobando el dolo tanto los casos de dolo directo como los de dolo eventual, y que se haya producido un perjuicio. Dicho perjuicio representa un doble papel, ya que, por un lado, es el resultado del delito y, por otro lado, es situación típica determinante de la penalidad, de forma que si no se produce el perjuicio, la conducta no será penada, razón por la cual la tentativa resulta impune. La actuación dolosa a la que se ha aludido puede consistir tanto en la causación como en la agravación de la insolvencia.

Respecto a lo que debe entenderse bajo el término «agravación», el Tribunal Supremo ha señalado, en sentencia de 12 de febrero de 1997:

«El tipo penal, tal como ha sido precisado en la doctrina, no sólo se da cuando las operaciones dolosas han causado la quiebra, sino también cuando las mismas han agravado la situación crítica de la entidad mercantil. Por agravación de ésta se debe entender el perjuicio injustificado de la masa de acreedores. En este sentido, es preciso señalar que la Ley Penal y su complemento normativo mercantil (art. 890 C. de C.), no requiere un mínimo de perjuicio patrimonial».

Introduce este artículo 260, en su apartado 1, el término de «crisis económica», concepto jurídico indeterminado, a no ser que se mencione como sinónimo de insolvencia, que para la doctrina mercantil y financiera presenta matices diferenciados. El concepto de insolvencia no es unívoco, pues se extiende a zonas imprecisas que van desde no pagar (sobreseer en el cumplimiento de las obligaciones) hasta no poder pagar, total o parcialmente, por carecer de patrimonio neto (activo inferior al pasivo exigible), es decir, por pérdida total del capital social (descapitalización, que no desbalance). Respecto a las expresiones «crisis económica»e «insolvencia» del referido art. 260, la conjunción «0» (situación de crisis económica o la insolvencia), en este y otros casos del CP, invita a considerar sinónimos los conceptos de crisis económica e insolvencia, y que se producen, en general, cuando el importe de las obligaciones exigibles resulte superior, en un momento dado, al de los bienes y derechos que sean realizables, pues aun admitiendo que no sean conceptos sinónimos (desde el punto de vista gramatical, que no jurídico) parece obvio que no toda crisis económica empresarial (disminución de beneficios, crecimiento, producto, mercado, etc.) acarrea

26 Bueren Roncero, Carlos, op. cit., pág. 11. 
el incumplimiento de obligaciones, luego la conclusión puede ser que el término «crisis económica» trata de abarcar toda la casuística que se produce, pero siempre dentro de los límites del tipo, es decir, el concurso, englobándolo en el concepto genérico señalado, cuando el importe de las obligaciones exigibles sea superior al de los bienes y derechos realizables, y que puede manifestarse en las dificultades de pago a acreedores (insolvencia).

Bueren ${ }^{27}$, después de destacar que este art. 260 recoge el tipo básico de los delitos concursales, expone que el resultado de la actuación debe ser la insolvencia o crisis económica del deudor, exigiéndose un nexo causal entre el comportamiento doloso y la producción del resultado, de tal forma que por «insolvencia» cabe entender aquella situación en la que el importe de las obligaciones exigibles superara al de los bienes y derechos realizables, mientras que el término «crisis económica» constituye un concepto indeterminado cuya interpretación se deja al juez, lo cual es criticable atendidos los principios imperantes en el ámbito penal, principalmente el de legalidad. Considero que se ha pretendido asimilar «crisis económica» con iliquidez o insolvencia provisional e «insolvencia» con descapitalización o ausencia de recursos propios.

El concepto de «crisis económica» fue definido correctamente, a mi juicio, en el Anteproyecto de Ley Concursal ${ }^{28}$, en los términos siguientes: «estado patrimonial que lesione o amenace gravemente el interés de los acreedores a la satisfacción normal y ordenada de sus créditos». Aunque se plantea como mera hipótesis, es de temer que los redactores de esta Ley Penal (nuestros parlamentarios, aunque más bien me inclino por los prelegisladores) hayan podido tener a la vista el citado Anteproyecto, cuyo art. 300 determina:

«Se calificará como culpable (el concurso) cuando en la producción o agravación de la crisis económica haya existido dolo o culpa grave del deudor persona física, de sus representantes legales, en su caso, o, tratándose de personas jurídicas, de sus administradores o liquidadores»;

y, en el art. 301:

«Se presumirá la existencia de dolo o culpa grave, sin posibilidad de prueba en contrario:... 2. ${ }^{\circ}$ Cuando (el deudor) se hubiese alzado con todo o parte de sus bienes».

27 Bueren Roncero, Carlos, op. cit., pág. 11

28 Redactado por la Ponencia Especial y revisado y aprobado por la Sección de Derecho Mercantil, con la colaboración de las Secciones de Derecho Civil y Derecho Procesal, de la Comisión General de Codificación; publicada por la Secretaría General Técnica del Ministerio de Justicia, Madrid, 1983. 
El Borrador del referido Anteproyecto de Ley Concursal presentado por la Comisión Codificadora, en septiembre de 2000, al Ministerio de Justicia, dispone en el art. 163:

"1. El concurso se calificará como culpable cuando en la generación o agravación del estado de insolvencia hubiera mediado dolo o culpa grave del deudor o, si los tuviere, de sus representantes legales y, en caso de persona jurídica, de sus administradores o liquidadores, de derecho o de hecho».

La Propuesta de Reforma de Ley Concursal ${ }^{29}$ en el art. 205.3 señala:

«El concurso se calificará como culpable, además, en los siguientes casos: $1 .^{\circ}$ Cuando el deudor se hubiera alzado con la totalidad o parte de sus bienes en perjuicio de sus acreedores o hubiera realizado cualquier acto de disposición patrimonial o generador de obligaciones con la finalidad de retrasar, dificultar o impedir la eficacia de un embargo en cualquier clase de ejecución que se hubiera iniciado o fuera de previsible iniciación».

El Borrador del Anteproyecto de Ley Concursal de la Comisión General de Codificación presentado en septiembre de 2000, así como el Anteproyecto de Ley preparado por el Ministerio de Justicia, con fecha 7 de septiembre de 2001, al igual que el Proyecto de Ley aprobado por el Consejo de Ministros, en sesión celebrada el 5 de julio de 2002, en el art. 163, dispone:

«1. El concurso se calificará como culpable cuando en la generación o agravación del estado de insolvencia hubiera mediado dolo o culpa grave del deudor o, si los tuviere, de sus representantes legales y, en caso de persona jurídica, de sus administradores o liquidadores, de derecho o de hecho. 2. En todo caso, el concurso se calificará como culpable cuando concurra cualquiera de los siguientes supuestos:... $4 .^{\circ}$ Cuando el deudor se hubiera alzado con la totalidad o parte de sus bienes en perjuicio de sus acreedores o hubiera realizado cualquier acto con efectos patrimoniales que retrase, dificulte o impida la eficacia de un embargo en cualquier clase de ejecución iniciada o de previsible iniciación».

Sin modificación alguna, durante el debate parlamentario, el mismo texto recoge la nueva Ley Concursal en el art. 164.

En los arts. 1..$^{\circ}$ y 9..$^{\circ}$ del referido Anteproyecto de 1983 se establece como presupuesto objetivo para la declaración del concurso la situación de crisis económica del deudor común y se especifican los hechos

29 Redactada por el Profesor Angel Rojo Fernández-Río. Suplemento al Boletín de Información núm. 1768, de 15.02.1996, del Ministerio de Justicia. 
reveladores de dicha situación. Esta posibilidad se apunta por el profesor Nieto Martín ${ }^{30}$ :

«...¿¿cuándo puede decirse que una empresa está en crisis económica? Hasta ahora poseemos dos conceptos económicos que pueden servirnos de introducción al concepto de crisis: "sobreendeudameinto" (desbalance) e "iliquidez". No obstante, es posible encontrar otra expresión, que habitualmente se utiliza en el derecho concursal, que nos acerca con mayor precisión al núcleo del concepto de crisis: "la amenaza de lesión a los intereses de los acreedores". Es más, si se realiza una interpretación auténtica del art. 260 esta última es la noción a la que el legislador probablemente quiere remitirnos con el empleo del término "crisis económica". En efecto, si escudriñamos en la génesis del art. 260 del CP vemos cómo el concepto de crisis económica está tomado de los trabajos preparatorios del Anteproyecto de Ley Concursal de 1983. El art. 260 del CP procede, casi sin modificaciones, del art. 256 del Proyecto de CP de 1980. Precepto que a su vez es reflejo del art. 300 del Anteproyecto de Ley Concursal de 1983: "El concurso se calificará de culpable o fortuito. Se calificará como culpable cuando en la producción o agravación de la crisis económica haya existido dolo o culpa grave del deudor...". Es cierto que entre ambos preceptos existen diferencias, pero aquí me interesa reseñar una coincidencia fundamental: la utilización del concepto de crisis económica. Pues bien, este término, era definido en el art. 9 del Anteproyecto de Ley Concursal como equivalente a: "amenaza de lesión de los intereses de los acreedores"...».

Una cuestión de tiempos verbales, en el mentado art. 260, dificulta su comprensión, dado el lenguaje penal, cuando se refiere a que la situación de crisis económica o insolvencia sea causada o agravada dolosamente por el deudor o persona que actúe en su nombre, y parece comprender temporalmente cualquier momento, anterior o posterior a la tramitación del proceso concursal, aunque durante ésta será más difícil, por virtud de la limitación de facultades al deudor concursado o su suspensión ex citado art. 40. Puede entenderse que agravar significa profundizar en la insolvencia. Se excluyen, al exigirse el dolo, las causadas o agravadas de manera fortuita o imprudente, y la determinación de cuándo hay dolo corresponde a los Tribunales, pero podrá presumirse su existencia cuando concurran alguno de los supuestos tasados en el citado art. $164.1^{31}$ de la Ley concursal.

30 Nieto Martín, Adán, El delito de quiebra. Valencia, Tirant lo Blanch, 2000, págs. 167-170.

31 «El concurso se calificará como culpable cuando en la generación o agravación del estado de insolvencia hubiera mediado dolo o culpa grave del deudor o, si los tuviere, de sus representantes legales y, en caso de persona jurídica, de sus administradores o liquidadores, de derecho o de hecho». 
Ferrer Barriendos ${ }^{32}$ analiza las cuestiones planteadas e interpreta que la expresión «situación de crisis económica» puede que no contenga elemento valorativo alguno, limitándose a referirse a la «situación» de hecho, sin más sentido de trascendencia jurídica, salvo la inevitable advertencia de que el Código Penal no se refiere a situaciones de hecho «preconcursales», sino a estados jurídicos ya declarados, según se desprende en enunciado inicial del mismo precepto, por lo que sería incoherente hablar de «situación de crisis económica o insolvencia» como algo distinto de un concurso de acreedores formalmente declarado. Coincide en la posibilidad de que la expresión «situación de crisis económica» sea el resultado de un poco cuidadoso trasplante de lo que dice el art. 300 del Anteproyecto de Ley Concursal, en su redacción por la Comisión de 1983. Curiosamente aquella redacción es uno de los aspectos significados de cambio de criterio en la definición que contiene la propuesta de Anteproyecto del profesor Rojo en 1995, al excluir la referencia a «estado de crisis económica» y referirse exclusivamente a la causación o agravación de la «insolvencia». Si realmente fuera el resultado de aquel trasplante del precepto citado del Anteproyecto de 1983, con la idea de que sirviera como punto referencial, de «momento» para la jurisprudencia y en su día por remisión a un texto concursal nuevo, se considera poco adecuado, pues el Anteproyecto de 1983 parte precisamente de una perspectiva de máxima anticipación de la intervención procesal en los estados de crisis económica y, consecuentemente, los actos concretos que tipifica como definitorios de la situación de «estado de crisis económica» no son los más adecuados para servir de soporte a la reacción penal. En todo caso, no sería acertada la interpretación de remitirse a estas circunstancias del anteproyecto concursal, porque la idea del legislador penal es la de crear un tipo amplio caracterizado por el dolo, pero no un tipo en blanco de remisión a un texto no vigente. Concluye su razonamiento y entiende que la expresión «la situación de crisis económica o la insolvencia» debería referirse esencialmente a aquellas situaciones de hecho que producen lo que habitualmente se denomina «iliquidez y/o insolvencia» y que el legislador penal ha intentado referirse a la realidad de las situaciones, con independencia de las calificaciones jurídicas.

Sobre participación de extraños (persona que actúe en su nombre), González Cussac ${ }^{33}$ analiza el concepto de inducción, cooperación necesaria o complicidad, y se detiene en la contribución de un asesor, que

32 Ferrer Barriendos, Agustín, op. cit., págs. 555-558.

33 GonZález CussaC, José Luis, «Insolvencias punibles», op. cit., vol. III, págs. 2185-2186. 
«consiste sólo en asesorar y no en efectuar otras actividades o ejercer además otras facultades. Ocurre, sin embargo, que dada la complejidad de las relaciones económicas y jurídicas características del tráfico mercantil, no siempre resultará sencillo trazar una nítida diferencia entre las labores de asesoramiento y la realización de otros actos, generalmente "en nombre y representación” del deudor. De ahí que en ocasiones las facultades de los profesionales sean múltiples. Y quizás por esta razón, en la mayoría de las veces nos encontraremos en el ámbito del artículo 31 del Código Penal, con lo cual, la complejidad de la estructura de ciertas sociedades, puede aumentar, modificar o derivar la solución. Pero en principio, está fórmula legal, se refiere exclusivamente a los autores y no a los partícipes, por lo que su tratamiento es indiferente hacerlo aquí o al estudiar el citado precepto. Un criterio orientativo, o cuanto menos a considerar, será si el asesor o profesional desempeña su labor desde fuera de la estructura social, o por el contrario se encuentra integrado en la plantilla de la empresa. Difícilmente puede hablarse de inducción dentro de las tareas propias de un asesor, ya sea interno o externo. Porque el artículo 28 del Código Penal requiere de una inducción directa a ejecutar los hechos constitutivos de delito. Esto es, determinar al deudor a la realización de la insolvencia, creándole la voluntad criminal. Recuérdese que la llamada incitación al deudor que ya ha resuelto o decidido cometer la quiebra (omnimodo facturus), no es auténtica inducción. En cualquier caso, como expresamente ha declarado la jurisprudencia, la responsabilidad criminal de los asesores a título de partícipes, no exonera de responsabilidad al deudor, esto es, al verdadero autor $(S$. de 5 de mayo de 1994). En lo relativo a la responsabilidad a título de cooperación necesaria o simple complicidad, debe hacerse desde dos consideraciones. La primera, referida sobre todo a los asesores o profesionales vinculados formalmente a las estructuras sociales, pasa por descartar su actuación a título de autor. Para ello habrá que atender a sus funciones y competencias, tanto en sentido formal, como en sentido material, para descartar que en realidad actúen como administradores de derecho o de hecho, y por tanto en régimen de coautoría. Igualmente deben descartarse los casos donde el asesor o profesional es manejado como un instrumento completamente ciego, que se comporta sin voluntad alguna. Nos encontraríamos ante hipótesis de autoría mediata».

En el descubrimiento y denuncia de este presunto delito, la administración concursal puede acopiar pruebas deducidas del ejercicio de sus funciones revisoras de la gestión económica del deudor, a través de la contabilidad, y será el órgano jurisdiccional penal quien establecerá qué actuaciones considera determinantes para causar o agravar dolosamente la situación de crisis económica o la insolvencia.

El citado art. 164.1 de la Ley Concursal califica de culpable la conducta del deudor por el mismo hecho que el art. 260.1 tipifica el delito 
de insolvencia punible, lo que permite deducir que cuando se califique el concurso culpable por dicha causa, podrá deducirse testimonio para el Juzgado de Instrucción, por si se hubiese incurrido en dicho ilícito penal.

En el apartado 2 del art. 260 se mencionan términos imprecisos para graduar la pena: cuantía del perjuicio inferido a los acreedores, su número y condición económica, que quedará al arbitrio judicial, previo dictamen pericial, si así se acuerda.

En el apartado 3 del art. 260 se deroga tácitamente el art. 896 del C. de C., ahora expresamente derogado por la Ley Concursal, al permitir se persiga este delito y otros singulares relacionados con él, sin esperar a la conclusión del proceso civil.

En el nuevo concurso de acreedores, queda clara la independencia de ambas jurisdicciones, según la exposición de motivos:

«Los efectos de la calificación se limitan a la esfera civil, sin trascender a la penal ni constituir condición de prejudicialidad ${ }^{34}$ para la persecución de las conductas que pudieran ser constitutivas de delitos. La ley mantiene la neta separación de ilícitos civiles y penales en esta materia».

El inciso final del apartado 3 del art. 260 establece que el importe de la responsabilidad civil derivada de dichos delitos deberá incorporarse a la masa, y ello será posible: a) si se condena a los administradores de sociedades mercantiles; b) cuando se tratase de un empresario individual, en particular, si alcanzare mejor fortuna, pues todos sus bienes integran la masa activa del concurso; y, c) si se condenare a los cómplices de estos delitos.

Ferrer Barriendos ${ }^{35}$ entiende que la operatividad del proceso penal, una vez liberado de la traba del presupuesto de procedibilidad, va a constituir un mecanismo que superará o completará, tanto en la satisfacción de sentimientos vindicativos de los acreedores, como en utilidad patrimonial, a las actuales regulaciones de la sección de calificación y también la de reintegración de la masa el concurso, significando que muchas de las acciones rescisorias y de impugnación del art. 71 y

\footnotetext{
34 «Artículo 189. Prejudicialidad penal. 1. La incoación de procedimientos criminales relacionados con el concurso no provocará la suspensión de la tramitación de éste. 2. Admitida a trámite querella o denuncia criminal sobre hechos que tengan relación o influencia en el concurso, será de competencia del juez de éste adoptar las medidas de retención de pagos a los acreedores inculpados u otras análogas que permitan continuar la tramitación del procedimiento concursal, siempre que no hagan imposible la ejecución de los pronunciamientos patrimoniales de la eventual condena penal».

35 Ferrer Barriendos, Agustín, op. cit., pág. 560.
} 
siguientes de la Ley concursal están basadas en circunstancias de hecho (simulaciones, confabulaciones), que quedan bajo la órbita de preceptos penales concretos o que constituyen agravación de la insolvencia, y que, por vía responsabilidad civil derivada de la acción penal, podrán volver a la masa en condiciones más eficaces.

En el apartado 4 del art. 260 se declara la independencia del orden civil y penal, cuando establece que la calificación de la insolvencia en el orden civil no vincula a la jurisdicción penal, al igual que dispone el art. $163.2^{36}$ de la Ley Concursal. Según el magistrado Bueren ${ }^{37}$, esto implica un avance significativo para los acreedores respecto de la situación anterior, en la que el acreedor defraudado tenía que esperar durante años para poder perseguir en vía penal al deudor insolvente.

\subsection{Falsedad contable en procesos concursales}

El art. 261 castiga la falsedad contable o falsedades instrumentales y puede lograr se eviten algunos fraudes procesales, si consigue salir al paso del abuso que cunde, a veces, en el escenario judicial, al sancionar la presentación de datos falsos relativos al estado contable, más bien documentos contables, que integran las cuentas anuales (balance, cuenta de pérdidas y ganancias y memoria) o estados financieros intermedios, cuando se acompañan a la solicitud de declaración de concurso, es decir, puede cometerse antes de la declaración de concurso, al provocar indebidamente su inicio.

González Cussac ${ }^{38}$ observa:

«... ha de señalarse que el artículo 261 tiene una evidente naturaleza "falsaria", esto es, que responde a la idea de simulación. Se castiga pues, al sujeto que presenta como auténtico o verdadero, algo que no lo es. Aquí consiste en presentar como verdaderos determinados datos contables que no lo son; o sea, simular que son ciertos... Por tanto, se castiga faltar a la verdad en la contabilidad, plasmarlo documentalmente y presentarlo a las personas encargadas de declarar el concurso.... Para terminar de afinar la naturaleza del artículo 261, es necesario mostrar su similitud con la llamada «estafa procesal», como así ha sido indicado por la doctrina (Nieto Martín). Esta se contiene ahora en el artículo 250.2. ${ }^{\circ}$, sancionando cualquier comportamiento realizado con engaño y ánimo de lucro, tendente a inducir a error a un

36 «La calificación no vinculará a los jueces y tribunales del orden jurisdiccional penal que, en su caso, entiendan de actuaciones del deudor que pudieran ser constitutivas de delito».

37 Bueren Roncero, Carlos, op. cit., pág. 14.

38 GonZÁlez CuSSAC, José Luis, «Insolvencias punibles», op. cit., vol. III, págs. 2280-2281. 
juez, para que como consecuencia del mismo, dicte una resolución injusta, que comportará un acto de disposición patrimonial en perjuicio de tercero. Aquí, el engaño ha de consistir precisamente en la simulación de un pleito, de forma que se subvierta la naturaleza del proceso (Vives Antón/González Cussac: “Comentarios...”, vol. II; y SS de 7 de junio de 1989; 23 de febrero de 1990 y 30 de noviembre de 1992). $Y$ en verdad son muchos los rasgos comunes entre ambas disposiciones, como ocurre con la nota esencial de instrumentalizar a un juez, mediante la consabida secuencia de engaño, error, declaración judicial, acto de disposición patrimonial, y perjuicio a terceros. Ahora bien, también existen diferencias esenciales entre ambas normas. Porque además de las peculiaridades ya apuntadas del artículo 261 (ámbito, contabilidad y finalidad específica), hay que destacar otras dos. La primera, que en ninguna clase de insolvencia existe acto de disposición del patrimonio ajeno, sino que por su naturaleza, el sujeto activo comete la infracción a través de su propio patrimonio, lesionando así el derecho de crédito de los acreedores. Y segundo, que aquí el engaño no consiste necesariamente en la simulación de un pleito, esto es, en un fraude que subvierta la naturaleza del proceso, sino que el engaño radica justamente en la presentación de datos contables falsos».

Maza Martín ${ }^{39}$ concreta:

«El agente del delito será, en principio, el deudor que pretende su propia declaración concursal... Sin embargo, hay que tener en cuenta que, como el delito consiste en el uso del documento falso, la conducta de quien llevara a cabo esa falsedad, si no lo hiciera en connivencia con el deudor, no pudiendo, por lo tanto, ser considerado copartícipe de la infracción, resultará impune, al tratarse de una mera "falsedad ideológica”. Algún autor se plantea la posibilidad de que también fueren sujetos activos de esta figura los acreedores, que perseguirían forzar al deudor al abono de su deuda, ante la "amenaza" del procedimiento concursal. Aunque esa hipótesis es, en principio, rechazada por la mayor parte de la doctrina, tal posibilidad, a mi juicio, bien excepcional en la práctica, encajaría perfectamente en la descripción típica del precepto, por lo que considero que no puede excluirse totalmente».

Este precepto, según comenta Ramos Rubio ${ }^{40}$, constituye una novedad relativa en el nuevo CP y trae a la memoria, de nuevo, el Anteproyecto de Ley Concursal ${ }^{41}$, cuyo art. 302 señala:

39 Maza Martín, José Manuel, op. cit., págs. 331-332.

40 Ramos Rubio, Carlos, op. cit., pág. 37.

41 Anteproyecto de Ley Concursal, Madrid, Secretaría General Técnica del Ministerio de Justicia, 1983. 
"En el concurso de un empresario se presumirá, además, la existencia de dolo o culpa grave... 3. . . Cuando hubiese cometido falsedad en la contabilidad o en la relación de acreedores y demás documentos que hubiera aportado al concurso».

El requisito de la finalidad, destacado en este art. 261: «lograr indebidamente la declaración de aquél», requiere un análisis más detenido, salvo que se relacione con los arts. 6.3 y 7 de la Ley Concursal.

González Cussac ${ }^{42}$ comenta:

«... la presentación de datos falsos ajenos a la contabilidad no constituye el objeto de esta figura, por lo que deberán aplicarse las reglas generales. De conformidad a la legislación mercantil, la expresión legal ha de entenderse referida exclusivamente a la valoración de las partidas contables, a los libros de contabilidad y a las cuentas de activo y pasivo (Moreno Verdejo). Es indiferente que estos datos falsos contables afecten a la situación financiera, fiscal o empresarial (Quintero Olivares). Se ha destacado en este sentido, la importancia de la contabilidad, que se consagra en las exigencias legales que rodean la documentación que ha de presentarse en el marco de un procedimiento concursal... Todo ello pues, pone de manifiesto la transcendencia de la contabilidad, y especialmente de su elemento más representativo que es el balance. De ahí la necesidad que sea ajustado a la realidad (Sagrera Tizón). Por tanto, el concepto de "estado contable" no se extiende a la memoria, ni tampoco a las certificaciones del consejo de administración. Su falsificación y presentación deberá sancionarse, en su caso, conforme a los artículos 392 y 396 respectivamente».

Maza Martín ${ }^{43}$ puntualiza:

«La conducta típica consiste en la presentación de datos falsos, de carácter contable y consignados documentalmente, en procedimiento de concurso. Por lo tanto, lo sancionado no es la confección del documento con contenido falso, sino su uso, presentándolo en un procedimiento civil, de las clases dichas.... Esos datos contenidos en el documento deberán ser además efectivamente falsos, por lo que no estaremos ante este delito cuando se trate, tan sólo, de meras discrepancias contables. Por otro lado, la falsedad ha de constar en verdaderos documentos de contabilidad (especialmente los balances), por lo que su incorporación en otros, como, por ejemplo, las memorias a aportar por el deudor o las proposiciones de pago, no constituye delito. Sí que lo sería, por contra, la inclusión, en el pasivo de la ejecución colectiva, de créditos inexistentes. Imprescindible asimismo es que el autor de la conducta conozca la falsedad de lo que presenta, pues, expresamente,

42 GonZÁLEZ CuSSAC, José Luis, «Insolvencias punibles», op. cit., vol. III, págs. 2284-2285.

${ }^{43}$ Maza Martín, José Manuel, op. cit., págs. 332-333. 
la norma incluye la frase "a sabiendas". Por lo que no son posibles las formas culposas... La presentación habrá de efectuarse, en todo caso, antes de la declaración de la situación de ejecución colectiva. La aportación de datos falsos posterior a este momento quedará fuera de la descripción del artículo comentado».

En el nuevo concurso de acreedores, cuando el deudor estuviera obligado legalmente a llevar contabilidad, deberá presentar determinados documentos contables $e x$ art. $6.3 \mathrm{y}$, si hubiera cometido inexactitud grave en cualquiera de los documentos acompañados a la solicitud, es causa de calificación de concurso culpable, como presunción absoluta, según el art. 164.2.2. ${ }^{\circ 44}$ de la Ley Concursal. Sin embargo, considero que si los acreedores instantes de la solicitud de concurso necesario de su deudor presentasen datos falsos relativos al estado contable (extractos de cuenta, documentos de las cuentas anuales: balance, cuenta de pérdidas y ganancias y memoria) para lograr indebidamente aquella declaración, pueden incurrir en el delito tipificado en este art. 261. No obstante, González Cussac ${ }^{45}$ mantiene el criterio de que el sujeto activo puede ser cualquiera que tenga capacidad para presentar datos falsos en un procedimiento de quiebra, concurso o suspensión y que el tipo requiere que éste sea necesariamente el deudor, pues sólo él está inmerso en un procedimiento concursal y sólo él puede aportar datos sobre su estado contable. Es decir, que de acuerdo a la legislación mercantil, sólo el deudor aparece obligado a presentar la contabilidad de sus negocios, de modo que la conducta típica de presentar datos falsos, sólo puede cometerse por quien normativamente tiene la obligación de hacerlo. De esta forma la autoría queda estrechamente vinculada y determinada por la descripción de la conducta típica. De ahí que si sólo el deudor está obligado a presentar su contabilidad, sólo él puede presentarla, luego sólo el deudor puede ejecutar directamente el hecho típico. En conclusión, para ser autores en sentido estricto (art. 28 primero CP) debe poseerse la condición de deudor. Como quiera que sólo puede ser cometido por el deudor, conforma un delito especial, en el que han de tenerse presentes las reglas generales aplicables a esta clase de infracciones. En cualquier caso, al tratarse de un delito «especial propio», sólo podrá hablarse de «autoría» si el sujeto ostenta la condición de

44 «2. En todo caso, el concurso se calificará como culpable cuando concurra cualquiera de los siguientes supuestos:... $2{ }^{\circ}$ Cuando el deudor hubiera cometido inexactitud grave en cualquiera de los documentos acompañados a la solicitud de declaración de concurso o presentados durante la tramitación del procedimiento, o hubiera acompañado o presentado documentos falsos».

45 GonzÁlez CussaC, José Luis, «Insolvencias punibles», op. cit., vol. III, pág. 2290. 
deudor. De igual forma, únicamente existirá «coautoría», si además de la ejecución conjunta y del acuerdo de voluntades, todos los sujetos poseen la condición de deudores. Quienes no la tengan, responderán en su caso como partícipes. Y, del mismo modo, «la autoría mediata» se dará exclusivamente en los supuestos en los que el sujeto cualificado, esto es, el deudor, se sirva de un sujeto no cualificado o extraneus, como instrumento para realizar el tipo. Pero nunca podrá estimarse en el caso contrario.

Además, se ha planteado la posibilidad de que se castigue a los administradores concursales, si incluyesen datos falsos relativos al estado contable del deudor en el informe que vienen obligados a emitir, ex art. 75 de la Ley Concursal. Me parece más seguro descartar tal posibilidad, pues el art. $261 \mathrm{del} \mathrm{C.} \mathrm{Penal} \mathrm{considera} \mathrm{solamente} \mathrm{autor} \mathrm{al} \mathrm{deudor.} \mathrm{Otra}$ cosa es que los órganos auxiliares concursales puedan incurrir en delitos de falso testimonio ex arts. 459 y 460 del C. Penal, si faltaren a la verdad maliciosamente en su dictamen o la alterare con reticencias, inexactitudes o silenciando hechos o datos relevantes que les fueran conocidos.

Bueren $^{46}$ realiza la exégesis del art. $261 \mathrm{CP}$ :

«Introduce... la estafa procesal contable. Surge así un delito de estructura falsaria que precisa de la concurrencia de cuatro requisitos: la existencia de un procedimiento concursal, la presentación dolosa de datos falsos relativos al estado contable del deudor, que la conducta se haya realizado "a sabiendas" y la finalidad típica, consistente en la obtención indebida de la declaración concursal. El primer requisito, la existencia de un procedimiento concursal, se cumple con la declaración de concurso, declaración que adopta la forma de auto. Segundo, el término "presentar" hace referencia a la incorporación al proceso de los datos falsos relativos al estado contable, datos cuya falsedad presupone la comisión de un delito de falsedad en documento mercantil contemplado en el art. 392 CP. En tercer lugar, la conducta debe cometerse "a sabiendas", i.e., el conocimiento del agente debe abarcar la condición de falsos de los datos presentados, incluyéndose tanto el dolo directo como el eventual. En cuarto y último lugar, se requiere que la conducta persiga una finalidad típica, por lo que sólo en el caso de perseguirse el fin descrito, la conducta resulta punible; así, nos hallamos ante un elemento subjetivo del tipo. Esta finalidad típica consiste en la obtención indebida de la declaración del estado concursal. El adjetivo "indebida" alude a la manipulación de los datos que provoca una aparente situación de insolvencia...».

46 Bueren Roncero, Carlos, op. cit., págs. 11-12. 
Las funciones de la administración concursal permitirán poner de relieve, tras la revisión de la contabilidad del deudor, si se han dado los requisitos del tipo castigado por el art. $261 \mathrm{del} \mathrm{CP}$.

\section{Doctrina del Tribunal Supremo}

Acudiré a la jurisprudencia, propiamente dicha, sobre las insolvencias punibles tipificadas en el nuevo Código Penal, por lo que he recopilado, con la ayuda del profesor Fernández Teruelo ${ }^{47}$, las sentencias del Tribunal Supremo que resuelven sobre los artículos 257 a 261 del vigente Código Penal, para seleccionar algunas que considero más relevantes y acotarlas.

\subsection{Alzamiento de bienes en perjuicio de acreedores (art. 257.1.1. ${ }^{\circ}$ )}

—STS (Sala de lo Penal), de 12.03.2001:

«Fundamentos de Derecho. Quinto. 2. El delito de alzamiento de bienes constituye una infracción del deber de mantener íntegro el propio patrimonio como garantía universal en beneficio de cualquier acreedor (artículo 1911 del Código Civil). Aparece sucintamente definido en los artículos 519 CP/1973 y 257.1. ${ }^{\circ}$ CP/1995 que utilizan dos expresiones muy ricas en su significación, conforme han sido reiteradamente interpretadas por la Doctrina y por la jurisprudencia de esta Sala: "alzarse con sus bienes" y "en perjuicio de sus acreedores". Prescindiendo del concepto tradicional que tuvo en nuestra historia, referido al supuesto de fuga del deudor con desaparición de su persona y de su patrimonio, en la actualidad alzamiento de bienes equivale a la sustracción u ocultación que el deudor hace de todo o parte de su activo de modo que el acreedor encuentra dificultades para hallar bienes con los que poder cobrarse. Tal ocultación o sustracción, en la que caben modalidades muy diversas, puede hacerse de modo elemental apartando físicamente algún bien de forma que el acreedor ignore dónde se encuentra, o de modo más sofisticado, a través de algún negocio jurídico por medio del cual se enajena alguna cosa en favor de otra persona, generalmente parientes o amigos, o se constituye un gravamen o se sustrae algún elemento del activo patrimonial de modo que se impide o dificulta la posibilidad de realización ejecutiva, bien sea tal negocio real, porque efectivamente suponga una transmisión o gravamen verdaderos pero fraudulentos, como sucede en los casos tan frecuentes de

47 Fernández Teruelo, Javier G., Profesor de Derecho Penal. Facultad de Derecho de la Universidad de Oviedo. 
donaciones de padres a hijos, bien se trate de un negocio ficticio que, precisamente por tratarse de una simulación, no disminuye en verdad el patrimonio del deudor, pero en la práctica impide la ejecución del crédito porque aparece un tercero como titular del dominio o de un derecho que obstaculiza la vía de apremio.

La expresión "en perjuicio de sus acreedores" que utilizan los mencionados artículos ha sido siempre interpretada por la Doctrina de esta Sala, no como exigencia de un perjuicio real y efectivo en el titular del derecho de crédito, sino en el sentido de intención del deudor que pretende salvar algún bien o todo su patrimonio en su propio beneficio o en el de alguna otra persona, obstaculizando así la vía de ejecución que podrían seguir sus acreedores. De tal expresión así entendida se deducen tres consecuencias: 1. ${ }^{a}$ Han de existir uno o varios derechos de crédito reales y existentes, aunque puede ocurrir que, cuando la ocultación o sustracción se produce, todavía no fueran vencidos o fueran iliquidos $y$, por tanto, aún no exigibles, porque nada impide que, ante la perspectiva de una deuda, ya nacida pero todavía no ejercitable, alguien realice un verdadero y propio alzamiento de bienes; $2{ }^{a}$ La intención de perjudicar al acreedor o acreedores constituye un elemento subjetivo del tipo; $3 .^{a}$ Se configura así este tipo penal como un delito de tendencia en el que basta la intención de perjudicar a los acreedores mediante la ocultación que obstaculiza la vía de apremio, sin que sea necesario que esta vía ejecutiva quede total y absolutamente cerrada, ya que es suficiente con que se realice esa ocultación o sustracción de bienes, que es el resultado exigido en el tipo, pues el perjuicio real pertenece, no a la fase de perfección del delito, sino a la de su agotamiento.

La jurisprudencia de esta Sala viene exigiendo ese resultado para la consumación de este delito utilizando la expresión insolvencia y la doctrina encuadra esta infracción junto con los delitos de quiebra y concurso bajo la denominación de insolvencias punibles, criterio sistemático que acoge nuestro Código Penal vigente al incluir todos ellos en el mismo Capítulo VII del Título XIII del Libro II CP bajo la denominación "De las insolvencias punibles", de modo semejante al CP/1973. Conviene precisar que como resultado de este delito no se exige una insolvencia real y efectiva, sino una verdadera ocultación o sustracción de bienes que sea un obstáculo para el éxito de la vía de apremio. Y por eso las sentencias de esta Sala, que hablan de la insolvencia como resultado del alzamiento de bienes, siempre añaden los adjetivos total o parcial, real o ficticia (sentencias de 28.05.1979, 29.10.1988 y otras muchas), porque no es necesario en cada caso hacerle la cuenta al deudor para ver si tiene o no más activo que pasivo, lo cual no sería posible en muchos casos precisamente por la actitud de ocultación que adopta el deudor en estos supuestos.

Desde luego no se puede exigir que el acreedor, que se considera burlado por la actitud de alzamiento del deudor, tenga que ultimar el 
procedimiento de ejecución de su crédito hasta realizar los bienes embargados (sentencia de 6.05.1989), ni menos aun que tenga que agotar el patrimonio del deudor embargándole uno tras otro todos sus bienes para, de este modo, llegar a conocer su verdadera y real situación económica. Volvemos a repetir: lo que se exige como resultado en este delito es una efectiva sustracción de alguno o algunos bienes, que obstaculice razonablemente una posible vía de apremio con resultado positivo y suficiente para cubrir la deuda, de modo que el acreedor no tiene la carga de agotar el procedimiento de ejecución, precisamente porque el deudor con su actitud de alzamiento ha colocado su patrimonio en una situación tal que no es previsible la obtención de un resultado positivo en orden a la satisfacción del crédito.

Por lo tanto, producida la ocultación de bienes con intención probada de impedir a los acreedores la ejecución de sus derechos, ya no es necesario ningún otro requisito para la existencia de este delito. Ahora bien, es incompatible este delito con la existencia de algún bien no ocultado y conocido, de valor suficiente y libre de otras responsabilidades, en situación tal que permitiera prever una posible vía de apremio de resultado positivo para cubrir el importe de la deuda, porque en ese caso aquella ocultación no era tal y resultaba inocua para los intereses ajenos al propio deudor y porque nunca podría entenderse en estos supuestos que el aparente alzamiento se hubiera hecho con la intención de perjudicar a los acreedores, pues no parece lógico estimar que tal intención pudiera existir cuando se conservaron otros elementos del activo patrimonial susceptibles de una vía de ejecución con perspectivas de éxito.

En conclusión, el concepto de insolvencia, en cuanto resultado necesario exigido para el delito de alzamiento de bienes, no puede separarse de los adjetivos con los que la jurisprudencia de esta Sala lo suele acompañar, total o parcial, real o ficticia, y debe referirse siempre a los casos en los que la ocultación de elementos del activo del deudor produce un impedimento o un obstáculo importante para una posible actividad de ejecución de la deuda, de modo tal que sea razonable prever un fracaso en la eventual vía de apremio. En definitiva, algo que se encuentra ínsito en el mismo concepto de alzamiento de bienes en perjuicio de los acreedores y que no puede constituir un elemento del tipo nuevo a añadir a la definición del artículo 257.1.1. ${ }^{\circ}$ del Código Penal actual (519 CP anterior), salvo que se entienda en la forma antes expuesta».

\section{—STS (Sala de lo Penal), de 10.05.2001:}

«Fundamentos de Derecho. Unico. Partiendo de los hechos probados, a los que necesariamente nos hemos de ceñir dada la vía en realidad elegida por el recurrente, de ellos se puede inferir que si bien el primero de los requisitos (deuda líquida, vencida y exigible) queda reflejado en la narración fáctica (aunque pudiera ser dudoso desde otras 
perspectivas), lo que entendemos no concurren son los otros dos elementos, el objetivo de haberse creado una situación de insolvencia y el subjetivo del dolo específico de defraudar. Así tenemos:

a) Según se dice en el último párrafo de los hechos probados, el acusado reconoció desde el principio su deuda, habiéndola saldado antes del inicio del juicio, lo que provocó el apartamiento del deudor del procedimiento. No cabe duda que esto por sí solo no evita la comisión del delito, sino únicamente la aplicación, según acordó la Sala de instancia, de la atenuante 5. ${ }^{a}$ del artículo 21 del Código Penal (reparación del daño). Ahora bien, si nos fijamos en el contenido de la propia sentencia y en el examen de los autos en lo que aquí interesa, según nos permite el artículo 899 de la Ley de Enjuiciamiento Criminal, podemos llegar a la conclusión que esa restitución efectuada, sobre todo su modo de realizarla, nos pone de relieve que no existió verdadera ocultación del patrimonio para evitar el embargo de los bienes $y$, por tanto, que en el momento de llevarse a cabo esa medida el deudor no se hallaba en situación de insolvencia, ni total, ni parcial. No otra cosa significa que para realizar el pago de la deuda en cantidad nada despreciable (casi quince millones de pesetas) no necesitó acudir, ni a préstamos, ni a moratorias, ni a avales de clase alguna. Además hay que añadir que el embargo resultó fallido respecto a unas concretas participaciones sociales de las que había sido propietario el acusado, pero es casi seguro (por lo indicado) que tal resultado no se hubiera producido si el acreedor hubiera perseguido o señalado otros bienes pertenecientes al deudor que, lógicamente, existían.

b) De todo ello también cabe inferir que el requisito subjetivo de la intencionalidad no se puede apreciar en la acción llevada a cabo por el inculpado para colocarse en insolvencia en perjuicio del acreedor, pues ello no puede inferirse de la venta de unas acciones o participaciones en diversas sociedades cuando su patrimonio era más amplio y susceptible de responder adecuadamente de lo debido».

-STS (Sala 2. ${ }^{\mathrm{a}}$ ) 27.11. 2001:

Desestima el recurso de casación por infracción de Ley y de precepto constitucional interpuesto contra la sentencia de la Sección Cuarta de la Audiencia Provincial de Madrid condenando a los recurrentes. Expone la Sentencia que, hoy, el delito de alzamiento de bienes consiste en una actuación sobre los propios bienes destinada a mostrarse, real o aparentemente insolvente, parcial o totalmente, frente a todos o frente a parte de los acreedores, con el propósito directo de frustrar los créditos que hubieran podido satisfacerse sobre dichos bienes. Como resultado de este delito no se exige una insolvencia real y efectiva, sino una 
verdadera ocultación o sustracción de bienes que sea un obstáculo para el éxito de la vía de apremio. Por tanto, producida la ocultación de bienes con intención probada de impedir a los acreedores la ejecución de sus derechos, y el resultado de insolvencia, ya no es necesario acreditar ningún otro requisito para la existencia del delito. El concepto de insolvencia, según la Sala, en cuanto resultado necesario exigido para el delito de alzamiento de bienes, no puede separarse de los adjetivos total o parcial, real o ficticia, y debe referirse siempre a los casos en los que la ocultación de elementos del activo del deudor produce un impedimento importante para una posible actividad de ejecución de la deuda, de modo que sea razonable prever un fracaso en la eventual vía de apremio.

—STS (Sala de lo Penal), de 15.11.2002:

«Fundamentos de Derecho. Tercero. Es doctrina reiterada de esta Sala (cfr. Sentencias 14 de noviembre de 1999 [RJ 1999l8711], 23 de septiembre de 1998 [RJ 1999\8711] y 28 de febrero de 1996 [RJ 1996\1331], entre otras muchas) que el delito de alzamiento requiere para poder ser estimado la concurrencia de los siguientes elementos: a) la existencia de un derecho de crédito por parte del acreedor y, en consecuencia, de unas obligaciones dinerarias por parte del deudor, generalmente vencidas, líquidas y exigibles; b) la ocultación, enajenación real o ficticia, onerosa o gratuita de los propios bienes, o cualquier otra actividad que sustraiga los bienes citados al destino solutorio al que se hallan afectos; c) situación de insolvencia, total o parcial, real o aparente del deudor, consecuencia de dicha actividad; y d) concurrencia de un elemento subjetivo tendencial, consistente en la intención de causar perjuicio al acreedor, intención que excede del resultado típico, ya que el alzamiento es un delito de mera actividad, perteneciendo el perjuicio real a la fase de agotamiento del delito. $Y$ de modo bien patente concurren los anteriores elementos en el caso que examinamos: está perfectamente acreditado que el acusado tenía pendiente el pago del crédito que le fue concedido por la entidad que ejerce la acusación particular como igualmente resulta acreditado que el único bien con el que podía hacer frente al pago de esa deuda lo enajena, junto a su esposa, a favor de la madre de esta última, para evitar afrontar esa deuda en cuanto quedaba en situación de insolvencia. Es perfectamente lógica y acorde con las reglas de la experiencia la inferencia alcanzada por el Tribunal de instancia acerca del ánimo tendencial de ambos acusados de causar un perjuicio a los derechos de crédito que correspondían a la entidad acreedora. El Tribunal de instancia razona con acierto sobre la pluralidad de indicios que le han permitido alcanzar esa convicción que deja reflejada en el relato de hechos que se declaran probados.

Quinto. La declaración de nulidad de los negocios jurídicos celebrados por el deudor que se alza con sus bienes en perjuicio de sus 
acreedores es una consecuencia del vicio de la voluntad de que adolecen al estar impulsados por la decisión de dar cobertura lícita a un propósito delictivo que no es otro que defraudar las legítimas aspiraciones de los acreedores de hacerse pago con la totalidad de los bienes en virtud del principio de responsabilidad universal proclamado en el Código Civil. Existe una voluntad simulada cuyo único propósito es deshacerse del patrimonio con objeto de impedir u obstaculizar la aprehensión de los bienes como cobertura del pago en metálico de las obligaciones contraídas. La consecuencia lógica de todo ello, como ya se ha dicho, es la nulidad de los negocios jurídicos transmisivos y así se viene declarando de manera constante por la jurisprudencia de esta Sala (Cfr. Sentencia de esta sala de 8 de julio de 1992 [RJ 199216147]).

Es asimismo constante doctrina de esta Sala, como son exponentes, entre otras, las Sentencias de 4 noviembre 1981 (RJ 1981\4289), 3 diciembre 1983 (RJ 1983\6764), 11 junio 1984 (RJ 1984\3539), 14 diciembre 1985 (RJ 1985\6326), 19 enero 1988 (RJ 1985\6326) y 27 enero 1990, 16 marzo (RJ 1992 22274) y 12 junio 1992 (RJ 1992\5213) y 26 de marzo de 1993 (RJ 1993 2584), que la responsabilidad civil derivada del delito de alzamiento de bienes no debe comprender el montante de la obligación que el deudor quería eludir, debido a que esta obligación no nace del delito y porque la consumación de esta figura delictiva no va unida a la existencia de lesión o perjuicio patrimonial, sino a la colocación en un estado de insolvencia en perjuicio de los acreedores; por ello, lo que procede es la restauración del orden jurídico alterado por las acciones simuladas de venta de fincas declarando la nulidad de las escrituras públicas de compraventa de las fincas vendidas por los procesados, así como la cancelación de las respectivas inscripciones en el Registro de la Propiedad, reponiendo las fincas vendidas a la situación jurídica en que se encontraban en la fecha de los respectivos contratos, reintegrando al patrimonio del deudor los bienes indebidamente sacados del mismo, sin perjuicio de que los acreedores puedan ejercitar las acciones correspondientes para la efectividad de su crédito.

En el supuesto que examinamos, la transmisión del inmueble se realizó en fraude del acreedor y mediante actos viciados en cuanto, como señala la propia sentencia de instancia, se estableció un precio ficticio y no consta que ni siquiera se hubiera entregado, ni se produjo la transmisión real de la vivienda, y el Tribunal sentenciador expone que ello supone un negocio con causa ilícita que es nulo de pleno derecho y que no produce efecto alguno y la responsabilidad civil, acorde con la doctrina que se ha dejado antes expresada, entraña la restauración del orden jurídico y económico alterado por la conducta delictiva de los acusados y consecuentemente la nulidad de la venta realizada por los dos cónyuges condenados a la madre de la esposa, sin que pueda alegarse indefensión por parte de la compradora que ha sido parte en la causa y que ha podido ejercitar sus acciones, oponiéndose a esa declaración de responsabilidad civil, sin que sea óbice para esa declaración 
el que la compradora no haya sido condenada penalmente, y sin olvidar que la declaración de nulidad no empece a los derechos de crédito que pudiera ostentar contra su hija y yerno, limitándose la responsabilidad civil a un pronunciamiento de nulidad de la venta e inscripción en el registro, anulando los actos jurídicos patrimoniales que los acusados provocaron con su conducta delictiva y reintegrando así al patrimonio del deudor los bienes ilícitamente extraídos del mismo mediante tales actos viciados, ya que la declaración penal de la existencia del delito y del propósito defraudatorio nos sitúan ante un acto revestido de apariencia válida pero viciado por aplicación de las normas generales de la validez de los contratos (artículo 1261 del Código Civil [LEG 1889\27]) y más concretamente al estar afectado por una causa ilícita, lo que ocasiona la imposibilidad de surtir efecto alguno (artículo 1.275 del Código Civil)».

\subsection{Actos de disposición patrimonial o generadores de obligaciones obstativos al embargo de bienes (art. 257.1.2. ${ }^{\circ}$ )}

—STS (Sala de lo Penal), de 22.06.1999:

«Fundamentos de Derecho. Segundo. Infracción del art. 519 CP/1973. La Audiencia excluyó el dolo típico de este delito por las razones expuestas en el fundamento jurídico cuarto. Sin embargo, de ninguno de los argumentos de la Audiencia surge que los acusados ignoraran que mediante la venta realizada provocaban formalmente su insolvencia y a la vez frustraban la ejecución de las ejecuciones de las acciones del Banco. Dicho con otras palabras: al transferir la finca a su hija los acusados sabían que frustraban la posibilidad normal de su ejecución y que de esa manera, además, detraían del patrimonio una garantía de sus deudas con sus acreedores. Este conocimiento es suficiente para la configuración del dolo del tipo del art. 519 CP/1973 (art. 257.2. ${ }^{\circ}$ Código Penal). Por el contrario, la Audiencia ha partido de un concepto de "dolo específico" que se refiere, en realidad, a un cierto propósito de defraudar diverso del dolo en sí mismo. El tipo del alzamiento de bienes no requiere tal propósito, dado que el autor que conoce los elementos del tipo objetivo ya tiene todo el conocimiento necesario para comprender que produce un daño a sus acreedores. Por otra parte, el destino dado al dinero obtenido de la enajenación a su hija no excluye el dolo. En efecto, la cancelación de la hipoteca que ya existía sobre el inmueble y la devolución de préstamos a dos hijos, no excluyen el dolo, dado que en nada afectan el conocimiento que el autor tenía de los elementos del tipo».

_-STS (Sala de lo Penal), de 10.09.1999:

«Fundamentos de Derecho. Primero. Es cierto que el artículo 257.2 del Código Penal de 1995 hace expresa mención de aquel acto de dis- 
posición patrimonial o generador de obligaciones que dilate, dificulte o impida la eficacia de un embargo o de un procedimiento ejecutivo o de apremio, judicial, extrajudicial o administrativo, iniciado o de previsible iniciación, no obstante, olvida el recurrente que esa previsibilidad en la iniciación del proceso de reclamación, cuando el acto generador de la deuda ya se había producido, está implícito en el texto derogado, como ha sido recogido en reiteradas sentencias de esta Sala del Tribunal Supremo y el legislador del Código de 1995 ha venido a incluir expresamente en el tipo lo que la doctrina de esta Sala venía entendiendo igualmente abarcado por el delito de alzamiento de bienes tipificado en el artículo 519 del Código Penal de 1973, es decir, todos aquellos supuestos en los que se ha producido el hecho generador de la deuda aunque ésta aún no se haya ejercitado y el deudor provoca una situación perjudicial para los derechos económicos del acreedor.

Ciertamente, así lo ha venido declarando esta Sala como son exponentes, entre otras, las siguientes sentencias:

a) Sentencia de 8 de octubre de 1996 en la que se expresa que: «el requisito objetivo que exige el tipo lo constituye la existencia de uno o varios créditos reales y exigibles en su día de los que sea deudor el acusado del delito, sin la necesidad de que esos créditos estén vencidos o fueran líquidos en el momento del alzamiento, de ahí que digamos "exigibles en su día", pues entender la necesidad del vencimiento como requisito comisorio sería tanto como desnaturalizar la esencia de este acto defraudatorio, ya que es precisamente el temor a que llegue el momento del cumplimiento de la deuda lo que induce en pura lógica al vendedor a evitarlo con la necesaria anticipación, deshaciéndose de todos sus bienes o parte de ellos para así caer en insolvencia total o parcial e impedir a los acreedores o dificultarles el cobro de lo debido...».

b) En la Sentencia de esta Sala, de 8 de octubre de 1993, se dice que: «el delito de alzamiento de bienes requiere, para su apreciación y nacimiento a la vida jurídica, de los siguientes elementos: a) la existencia de uno o más créditos contra el sujeto activo, generalmente preexistentes y reales, y de ordinario vencidos, líquidos y exigibles, si bien es frecuente que los defraudadores, ante la inminencia del advenimiento de un crédito, se adelanta a su vencimiento, liquidez o exigibilidad, frustrando las legítimas expectativas de los acreedores, mediante la adopción de medidas de desposesión de sus bienes, con el fin de burlar los derechos de aquellos y eludir así su responsabilidad patrimonial; b) un elemento dinámico o de la actividad, consistente en destruir u ocultar su activo, real o ficticiamente; c) un elemento tendencial, finalístico o dolo específico de defraudar las expectativas legítimas generadas en el acreedor de poder cobrar sus 
créditos, y d) que como consecuencia de las maniobras torticeras y defraudatorias devenga el deudor total o parcialmente insolvente, o experimente una acusada, aunque ficticia, disminución de su acervo patrimonial, imposibilitando o dificultando el cobro de sus créditos a los acreedores (vid. SS., entre otras muchas, 24 noviembre 1989, 2 noviembre 1990 y 21 enero y 14 febrero 1992)».

c) En la Sentencia de esta Sala de 25 de febrero de 1993, en un supuesto parecido al que ahora examinamos, se declara que «si bien es cierto que la escritura de capitulaciones matrimoniales fue anterior al señalamiento de la indemnización... el recurrente, pues, ante la perspectiva de la resolución del contrato y señalamiento de la indemnización ya solicitada, el 21 mayo, otorga la escritura de capitulaciones matrimoniales el 3 junio anterior, en la cual, se adjudica a su esposa el único bien inmueble existente en la sociedad de gananciales, de tal forma, que aunque la fijación de la indemnización fue un mes después de aquel otorgamiento, dicha adjudicación provocó la imposibilidad de hacerla efectiva, y en consecuencia, se le declare insolvente por la Magistratura. La Sentencia de esta Sala de 26.02.1990 declaró que, aunque han de existir uno o varios derechos de crédito reales y existentes, puede ocurrir que cuando la ocultación se produce, no fueran vencidos o fueran ilíquidos, y por ende, aún no exigibles, pero ello no impide que, ante la perspectiva de una deuda ya nacida, pero aún no ejercitable, alguien realice un verdadero y propio alzamiento de bienes...».

d) En la Sentencia de 11 de septiembre de 1992 se expresa que: «también constituye doctrina de esta Sala, harto reiterada en estos últimos años, la de que el delito de alzamiento de bienes existe y se consuma aunque la actividad ocultadora del agente se origina y produzca en momentos en que el crédito todavía no puede estimarse vencido, y, por ende, exigible; siendo frecuente que los defraudadores, avistando tal vencimiento futuro, se anticipen al mismo, tratando de frustrar las futuras y legítimas expectativas de sus acreedores (cfr., entre muchas, SS. 4.02.1991, 6.03.1991, 20.04.1991 y 4.07.1991)».

e) Y en la Sentencia de 24 de noviembre de 1989 se expresa que «esta figura delictiva, ha sido estudiada reiteradamente por este Tribunal (v. SS. 27.09.1973, 11.01.1974, 31.01 y 6.06.1977, 15.04 y 30.12.1978, 28.05.1979, 17.10.1981, 10.2 y 7.03.1986, 22.4 y 4, 7, 8 y 27.11.1987 y 29.06.1989), deduciéndose, de esa doctrina jurisprudencial y de las aportaciones de la doctrina científica que, los requisitos o elementos estructurales de la infracción analizada, son los siguientes: $10^{\circ}$ Un punto de partida o presupuesto básico, integrado por la existencia de uno más créditos, generalmente, preexistentes, reales, y de ordinario venci- 
dos líquidos y exigibles, empleándose las locuciones o adverbios "generalmente" o "de ordinario", pues es muy frecuente que, los defraudadores, ante la inminencia del vencimiento de un crédito futuro, de su liquidez o de su irremisible, y ya citado, vencimiento, augurando un evidente perjuicio para sus intereses patrimoniales, se anticipen o adelanten al nacimiento del crédito o créditos, o a su vencimiento, liquidez o exigibilidad, frustrando o abortando las futuras y legítimas expectativas de sus acreedores, mediante la adopción de medidas de desposesión de sus bienes, tendentes a burlar y eludir su responsabilidad patrimonial, la que, como ya se ha dicho, no por tener que materializarse en el futuro, dejará de llegar y constituir amenaza potencial para el deudor remiso en el cumplimiento de sus obligaciones...».

Segundo. Queda perfectamente aclarado en el relato histórico de la sentencia de instancia que al acusado, cuando otorgó la escritura de capitulaciones matrimoniales, ya le constaba que el señor F. le había reclamado, con anterioridad, la cantidad que con engaño le había entregado y que era inminente la presentación de una denuncia que podría generar un pronunciamiento sobre responsabilidad civil cuya eficacia quedaba frustrada, como pudo comprobarse con posterioridad, con la adjudicación de bienes realizada a favor de su esposa.

En orden al elemento subjetivo del delito, es doctrina reiterada de esta Sala que se cumple cuando concurre un ánimo o propósito encaminado a defraudar las legítimas expectativas de los acreedores eludiendo el pago o cumplimiento de sus obligaciones merced a la desposesión de sus bienes, ocultándolos, enajenándolos o haciéndolos desaparecer mediante actos o negocios jurídicos fingidos que denotan el deseo de eludir la responsabilidad patrimonial que le pueda ser exigible, que en este caso, como bien razona el Tribunal de instancia, se infiere de un otorgamiento de capitulaciones matrimoniales que, a falta de otra explicación lógica, responde al intento de sustraer el dinero recibido del denunciante de los efectos de la acción penal que iba a ejercitar.

$Y$, por último, respecto a la inexistencia de una situación de insolvencia legal o fingida, lo cierto es que la expresión "en perjuicio de sus acreedores”, que emplea la dicción del art. 519 CP, ha sido interpretada por la doctrina de esta Sala —cfr. SS. 13.02.1992, 14.02.1992, 13.05.1992 y 17.09.1992—, no como exigencia de un perjuicio real y efectivo en el titular de un derecho de crédito, sino en el sentido de intención del deudor que pretende poner a salvo algún bien o todo su patrimonio en su propio beneficio o en el de alguna persona muy allegada, obstaculizando así la vía de apremio de los acreedores. Es por ello que el alzamiento de bienes se configura como un delito de tendencia en el que basta que se lleve a cabo esa ocultación de bienes para que se dé el resultado exigido por el tipo, ya que el perjuicio real no pertenece a la fase de perfección del delito sino a la de agotamiento. Y en el su- 
puesto que examinamos igualmente se pronuncia el Tribunal de instancia sobre la lograda ocultación de bienes mediante la disolución de la sociedad de gananciales y la desposesión sobre los inmuebles de que era titular el marido, dificultando los exigibles derechos económicos del denunciante, como ha resultado evidente de las actuaciones practicadas en las que el acusado, tras ser requerido de pago, ha manifestado carecer de bienes para afrontar la deuda y que necesitaba solicitar un crédito, lo que tampoco queda acreditado que hubiera hecho, habiendo satisfecho únicamente una cantidad mínima de la suma fijada como responsabilidad civil en el proceso penal».

—STS (Sala de lo Penal), de 21.01.2000:

«Fundamentos de Derecho. Tercero. Ha de señalarse, asimismo, que el hecho de que se hubiese acordado el desahucio del acusado del local donde ejercía su negocio, es en realidad irrelevante, pues el mismo ha reconocido de modo expreso que el negocio fue continuado en el mismo local a través de un nuevo contrato arrendaticio por una sociedad constituida ad hoc por su esposa y su hijo a la que de facto se traspasó el "espacio comercial" como señala el hecho probado (es decir, el "fondo de comercio" incluida la "clientela" al continuar ejercitando la misma actividad comercial en el mismo lugar), sin figurar formalmente el acusado (aunque reconoce que continuó atendiendo el negocio en calidad de "asesor") para evitar que la empresa familiar receptora del activo negocial tuviese que responder también del pasivo, y de ese modo burlar el embargo, expresamente trabado con anterioridad, sobre los "frutos" del negocio por su principal proveedor. Es decir que, embargados los frutos de un negocio de fotografía instalado en una céntrica calle valenciana para responder de una sustanciosa deuda con su proveedor ("Kodak"), el acusado traspasa la tienda a una sociedad constituida por su esposa y su hijo, de modo que los "frutos" del negocio, que continúa abierto y funcionando en el mismo lugar, con la misma clientela, dedicado a la misma actividad comercial y atendido por el mismo grupo familiar, quedan formalmente liberados del embargo, haciendo ineficaz la medida garantizadora judicialmente acordada. La maniobra fraudulenta es tan manifiesta que excusa de cualquier consideración adicional, justificándose plenamente la condena impuesta por el delito del art. 257 del Código Penal de 1995».

\section{—STS (Sala de lo Penal), de 12.04.2000:}

«Fundamentos de Derecho. Primero. Debe tenerse en cuenta que el delito por el que han sido condenados, de insolvencia punible previsto y penado en el art. 257.1.2. ${ }^{\circ}$ del Código Penal se articula por la conjunción de los siguientes elementos:

a) Existencia de créditos vencidos, líquidos y exigibles por parte de unos acreedores, constituidos en el presente caso por la resolu- 
ción anticipada del préstamo concedido por Bancaja al concurrir los requisitos pactados en el contrato.

b) La sustracción por el deudor al destino solutorio de sus obligaciones, de bienes propios, realizado de cualquier modo, tales como enajenación real o ficticia, onerosa o gratuita o simulación fraudulenta de créditos. En el presente caso se está en presencia de unas fraudulentas escrituras públicas de donación de bienes inmuebles efectuadas a los hijos del matrimonio.

c) La consecución de un estado de insolvencia real o aparente, ya sea total o parcial. $Y$ en el presente caso con las enajenaciones efectuadas el matrimonio se quedó sin patrimonio.

d) La concurrencia como hilo conductor que encauza y da sentido a todas las operaciones, de un dolo específico de causar perjuicio a los acreedores, que actúa como elemento subjetivo tendencial, debiéndose recordar que el delito de alzamiento está concebido como mera actividad —o si se quiere de resultado en cuanto a la ocultación-en la medida que no requiere la real causación del perjuicio a los acreedores, por ello puede decirse que se consuma con la realidad del alzamiento de los bienes a través de su ocultación, pero no es un delito de lesión, porque no exige la realidad del perjuicio que se buscaba».

—STS (Sala de lo Penal), de 31.01.2001:

«Fundamentos de Derecho. Segundo. Es doctrina reiterada de esta Sala (cfr. Sentencias 14 de noviembre de 1999, 23 de septiembre de 1998 y 28 de febrero de 1996, entre otras muchas) que el delito de alzamiento requiere para poder ser estimado la concurrencia de los siguientes elementos: a) la existencia de un derecho de crédito por parte del acreedor y, en consecuencia, de unas obligaciones dinerarias por parte del deudor, generalmente vencidas, líquidas y exigibles; b) la ocultación, enajenación real o ficticia, onerosa o gratuita de los propios bienes, o cualquier otra actividad que sustraiga los bienes citados al destino solutorio al que se hallan afectos; c) situación de insolvencia, total o parcial, real o aparente del deudor, consecuencia de dicha actividad; y d) concurrencia de un elemento subjetivo tendencial, consistente en la intención de causar perjuicio al acreedor.

$Y$ de modo bien patente concurren los anteriores elementos en el caso que examinamos: está perfectamente acreditado que los acusados, únicos socios de la Sociedad Anónima Laboral Transmagil, eran conscientes de que esta sociedad había sido condenada judicialmente a pagar una determinada cantidad a Transportes y Contenedores de Albacete, SL y que los únicos bienes que poseía la Sociedad Anónima Laboral mencionada eran los camiones, remolques y tarjetas de transporte que se mencionan en el relato fáctico y que pusieron a su nombre o al de parientes, sustrayéndolos del patrimonio de la sociedad y ha- 
ciendo ilusorio el derecho de crédito nacido del pronunciamiento condenatorio firme al no quedar bienes con los que poder afrontarlo.

Es de recordar la doctrina de esta Sala, como es exponente la Sentencia de 8 de octubre de 1996, de que el requisito objetivo que exige el tipo lo constituye la existencia de uno o varios créditos reales y exigibles en su día de los que sea deudor el acusado del delito, sin la necesidad de que esos créditos estén vencidos o fueran líquidos en el momento del alzamiento, pues entender la necesidad del vencimiento como requisito comisorio sería tanto como desnaturalizar la esencia de este acto defraudatorio, ya que es precisamente el temor a que llegue el momento del cumplimiento de la deuda lo que induce en pura lógica al vendedor a evitarlo con la necesaria anticipación, deshaciéndose de todos sus bienes o parte de ellos para así caer en insolvencia total o parcial e impedir a los acreedores o dificultarles el cobro de lo debido.

$Y$ en orden al tipo subjetivo es perfectamente lógica y acorde con las reglas de la experiencia y la lógica la inferencia alcanzada por el Tribunal de instancia acerca del ánimo tendencial de ambos recurrentes de causar un perjuicio a los derechos de crédito que correspondían a la Sociedad Mercantil Transportes y Contenedores Albacete, ya que queda fuera de duda que estos acusados tenían perfecto conocimiento de la reclamación judicial interpuesta por los representantes de esa Sociedad mercantil a la Sociedad Anónima Laboral de la que eran socios los cuatro acusados como igualmente eran conscientes de que los únicos bienes que tenía la sociedad para poder afrontar sus deudas eran los camiones, remolques y tarjetas de transporte que pusieron a su nombre o al nombre de allegados sin contraprestación alguna».

\section{_-STS (Sala de lo Penal), de 24.04.2001:}

«Fundamentos de Derecho. Tercero. En el caso de autos la sentencia censurada ha explicitado un conjunto de pruebas de naturaleza indiciaria, confluyentes todas a la culpabilidad de los cuatro acusados, cumpliendo con todos y cada uno de los requisitos jurisprudenciales que acabaron de reseñar. Así, se cuenta con los siguientes hechos indubitadamente acreditados:

a) La transacción se realiza dos días después del embargo. El inmueble se embarga el día 2 de octubre de 1996 y la venta se consumó el día 4 del mismo mes y año.

b) El parentesco existente entre el matrimonio vendedor y el comprador. Los compradores son la hermana y cuñado del vendedor.

c) El precio señalado en la venta, es menos de la mitad, que el de mercado, según tasación judicial, debidamente practicada, con intervención de los acusados.

d) La contradicción de los acusados, en sus declaraciones sumariales y en el plenario, entre unos y otros, en extremos relevantes, como el precio pagado, modo de abonarlo, etc. 
e) Carencia de motivo razonable de la adquisición.

- Por un lado, se alega por los compradores que su decisión de compra tenía por objeto estar cerca de la familia; pero el colegio de los niños está más próximo a la casa en la que se vive.

- Hasta el momento de dictar sentencia (enero de 1999), se mantiene la misma situación, en la ocupación de los inmuebles que antes de celebrar el contrato (octubre de 1996); esto es, vendedores y compradores, siguen viviendo en la misma casa.

- Los ingresos que por todos los conceptos perciben los compradores, alcanzarían, si aceptamos su versión, de tendencia lógicamente exculpatoria, 280.000 ptas. mensuales; estaban pagando una hipoteca de 40.000 ptas. y ahora añaden 100.000 ptas. más, al mes, en su endeudamiento.

- Los compradores sólo aportan documentos de pago a partir de 1998, en lugar de justificarlos desde que se realizó la venta; circunstancia anómala e inexplicable, en cualquier compraventa normal.

Con todos esos datos indiciarios, la Sala sentenciadora de instancia ha podido alcanzar conclusiones razonables. Razonable es la insuficiencia desvirtuadora de los argumentos de los recurrentes. Por mencionar alguno, reseñamos brevemente, los que tratan de atacar los indicios con mayor carga incriminatoria. Se dice por el vendedor, que desconoce el embargo; y no sabe qué responder, cuando se le exhibe el documento núm. 33, en que consta su práctica efectiva y la firma estampada de dicho acusado que no niega. Así como, considera poco menos que imposible, que con dos días de preparación se pueda formalizar, en una Notaría, un contrato de compraventa. La Sala de instancia, en su facultad crítica, ha entendido, con fundamento, que puede hacerse, sobre todo cuando se demanda del Notario una intervención propia de un caso de urgencia. Por tal debe entenderse, aquella intervención, que realizada extemporáneamente o con retraso, carecería de sentido. La situación demandaba rapidez, y el Notario, profesional en libre competencia, es lógico y usual que atienda el requerimiento de urgencia, hecho por un cliente, si quiere ser eficaz».

—STS (Sala de lo Penal), de 20.7.2004:

«Fundamentos de Derecho. Tercero. En el presente caso la inferencia obtenida por la Audiencia a partir de los actos dispositivos reflejados en el factum (ARP 2003, 103) no es ilógica o arbitraria y sí adecuada a las reglas de la lógica y la experiencia, sin que los recurrentes hayan aducido razones convincentes contrarias a dicha conclusión. Por otra parte, el artículo 257.2 CP, último inciso, se refiere a la realización de cualquier acto de disposición patrimonial que dilate, dificulte 
o impida la eficacia de un embargo o de un procedimiento ejecutivo... iniciado o de previsible iniciación, es decir, sobre la base de una deuda existente su condición de líquida y exigible basta con que esté determinada en relación con una fecha concreta, como sucede en el presente caso. En cuanto a la solvencia de los recurrentes, basta señalar que en el motivo anterior no han designado ni un sólo documento del que deducir la existencia de otros bienes suficientes para afrontar la deuda con independencia de los inmuebles que fueron objeto de disposición con posterioridad a la concesión del crédito. El derecho a la propiedad y las facultades del propietario están sujetas a las limitaciones establecidas por las Leyes, lo que significa que la invocación de los preceptos enunciados en el motivo carece por sí sola de eficacia para la resolución del caso, teniendo en cuenta que los hechos probados han sido correctamente subsumidos en el tipo penal aplicado, que no contiene positivamente una limitación del derecho de propiedad sino que en rigor lo que sanciona es el abuso de aquellas facultades en perjuicio de los acreedores legítimos».

\subsection{Actos de disposición de bienes o para contraer obligaciones con} la finalidad de eludir responsabilidades civiles ex delicto (art. 258)

—STS (Sala de lo Penal), de 9.06.1999:

«Fundamentos de Derecho. Cuarto. La modalidad específica de alzamiento de bienes orientada a eludir la responsabilidad civil ex delicto, tipificada por el legislador de 1995 en el art. 258 del Nuevo Código Penal, responde inicialmente a superar la polémica acerca de la subsunción típica en la modalidad básica del delito de alzamiento de bienes de aquellos supuestos en que el autor de un hecho delictivo se situaba en situación de insolvencia, para eludir las responsabilidades civiles derivadas de su acción, con anterioridad a que se dictase sentencia condenatoria. Por lo demás nos encontramos ante una concreción o especificación legal del tipo básico, sancionada con la misma pena, y que requiere la concurrencia de los elementos esenciales integradores del delito de alzamiento de bienes.

En el caso actual constan debidamente acreditados los elementos objetivos integradores del tipo delictivo: $\left.10^{\circ}\right)$ el acusado es responsable de un hecho delictivo, e incluso ha sido condenado por sentencia firme; $2^{\circ}{ }^{\circ}$ con posterioridad a su comisión, inmediatamente después de la sentencia condenatoria, ha realizado actos de disposición consistentes en vender en escritura pública el piso de su propiedad, único bien inmueble de su patrimonio, por un precio declarado de siete millones de pesetas, que el acusado hizo suyo; $3^{\circ}$ ) con dicho acto de disposición se hizo totalmente insolvente, al menos de forma aparente, quedando absolutamente desatendidas las responsabilidades civiles derivadas del hecho delictivo y definitivamente declaradas en la sentencia condena- 
toria, careciendo el acusado de otros bienes que pudiesen ser objeto de ejecución.

Por lo que se refiere al elemento subjetivo, es decir, haber actuado con la finalidad de eludir las responsabilidades civiles derivadas del hecho delictivo, al tratarse de un elemento intencional o interno no puede ser acreditado de modo objetivo y directo, debiendo necesariamente inferirse, de modo racional, a través del análisis de los datos externos o circunstancias objetivas que permitan deducir la concurrencia de dicha intencionalidad, conforme a las reglas del criterio humano, como conclusión lógica y racional de las circunstancias concurrentes.

En el caso actual la Sala sentenciadora infiere racionalmente dicha intencionalidad de circunstancias objetivas que la muestren de manera palmaria o evidente, como son, en primer lugar, la inmediatez con que se procede a la realización del acto de disposición tras la sentencia condenatoria (el acusado es condenado como autor de un hecho delictivo señalándose unas responsabilidades civiles superiores a doce millones de pesetas, en Sentencia de 21 de octubre de 1996, dictada de conformidad, e inmediatamente, el 5 de noviembre de 1996, realiza el acto de disposición, transfiriendo a nombre de un tercero el piso de su propiedad). En segundo lugar el hecho de que la vivienda transferida constituía el único bien inmueble que figuraba en el patrimonio del acusado, por lo cual con su transmisión se situaba en aparente situación de insolvencia, eliminando el único bien susceptible de ejecución forzosa. $Y$, en tercer lugar, la ocultación o distracción de los fondos supuestamente recibidos, siete millones de pesetas, como precio declarado en la escritura, que no se destinan ni siquiera en una mínima medida al pago de las responsabilidades civiles declaradas en la sentencia, poniendo claramente de relieve la intencionalidad de eludir su abono».

—STS (Sala de lo Penal), de 3.05.2001:

«Fundamentos de Derecho. Tercero. En el motivo tercero, que se ampara en el art. 849.1. ${ }^{\circ}$ LECr., se denuncia una infracción, por aplicación indebida, del art. 258 CP. Es posible que, en el ánimo de la parte recurrente, el éxito de este motivo se encuentre subordinado al del anterior y así parece confirmarlo la innecesaria alusión al derecho a la presunción de inocencia. La realidad es, sin embargo, que la aplicación debida del art. $258 \mathrm{CP}$ debe ser reconocida sin alteración alguna de la declaración de hechos probados. Esta ha quedado intacta tras la desestimación del segundo motivo de casación y ello no es obstáculo para que sea estimado el tercero. Se ha dicho que el art. $258 \mathrm{CP}$, introducido ex novo por el nuevo Texto de 1995, ha venido a zanjar una cuestión largamente discutida tanto en la doctrina como en la jurisprudencia: la de si constituye delito de alzamiento de bienes la conducta del autor de un delito que, antes de haber sido condenado por el mismo pero a sabiendas de que ha generado un perjuicio del que tendrá que responder mediante una indemnización, se alza con los bienes 
y se coloca en situación que le imposibilita o dificulta de modo sensible la satisfacción de dicha obligación. Entre quienes opinaban que la obligación ex delicto nace de la infracción criminal y quienes sostenían que la deuda no surge hasta que se dicta la Sentencia en que se declara la responsabilidad — penal y civil_el legislador se ha inclinado por la primera tesis. Hay que reconocer que no lo ha hecho con toda la claridad que hubiera sido deseable pues ha considerado sujeto activo del delito al "responsable" de cualquier hecho delictivo, pero ello no debe ser obstáculo para que el delito a que nos referimos pueda ser cometido simplemente con actos realizados "con posterioridad” a la comisión del hecho del que pueda derivarse la responsabilidad civil aunque ésta no haya sido declarada todavía. Esta interpretación parece la más razonable si se lee el nuevo tipo a la luz del anterior art. 257 en cuyo apartado $1.2^{\circ}$ se considera autor de delito equivalente al alzamiento de bienes previsto en el núm. $1 .^{\circ}$ del mismo apartado a quien, con el fin de perjudicar a sus acreedores, "realice cualquier acto de disposición patrimonial o generador de obligaciones que dilate, dificulte o impida la eficacia de un embargo o de un procedimiento ejecutivo o de apremio, judicial, extrajudicial o administrativo, iniciado o de previsible iniciación”. La última frase del precepto — “iniciado o de previsible iniciación"- es tan amplia que cabe preguntarse sobre la necesariedad de crear el tipo que hoy ocupa el art. 258 CP pues para quien ha cometido un hecho delictivo productor de un daño o perjuicio es más que previsible que se inicie contra él un procedimiento penal en que se aseguren primero y se ejecuten después las responsabilidades civiles nacidas del delito. Pero, con independencia de que haya sido necesario o no configurar el tipo específico de alzamiento del responsable de un delito, de lo que no puede dudarse ya es de que las acciones descritas en el mismo son punibles por el mero hecho de que se realicen después de la comisión del hecho delictivo y sin necesidad de que la responsabilidad sea declarada en sentencia.

Ahora bien, el nuevo delito debe ser interpretado también de acuerdo con las categorías elaboradas por la jurisprudencia en torno a la figura genérica del alzamiento de bienes que antes se contenía en el art. 519 CP/1973 y ahora lo está en el art. 257.1.1. ${ }^{\circ}$ CP vigente. Una característica negativa del delito, entroncada con ese esencial elemento subjetivo que es el propósito de defraudar al acreedor o acreedores burlando y eludiendo la responsabilidad patrimonial universal establecida en el art. 1911 CC —SS., entre otras muchas, de 2.11.1990, 14.02.1992 y 7.03.1996 - es que no hay alzamiento de bienes -SS. de 14.04.1990 y 25.10.1990 - cuando aquello que sustrae el deudor a la posible vía de apremio del acreedor fue empleado en el pago de otras deudas realmente existentes, pues lo que con este delito se castiga es la exclusión de algún elemento patrimonial a las posibilidades de ejecución de los acreedores en su globalidad y no individualmente determinados, ya que esta figura criminal no es una tipificación penal de la 
violación de las normas civiles o mercantiles relativas a la prelación de créditos. En esta misma línea, la S. de 2.12.1991 afirmaba ser "indudable" que la infracción del orden de prelación de créditos por parte del deudor no constituye por sí misma el comportamiento típico del delito de alzamiento de bienes. Se decía en esta Sentencia que dicha conducta estaba prevista en el art. 524.5. ${ }^{\circ} \mathrm{CP} / 1973$ pero sólo con referencia al concursado, lo que se consideraba una "primera razón” para excluir su tipicidad en relación con el art. 519. La conclusión es hoy aún más lógica si se tiene en cuenta la significación del tipo establecido en el art. 259 CP/1995, en el que la naturaleza delictiva de "cualquier acto de disposición patrimonial o generador de obligaciones - realizado por el deudor - destinado a pagar a uno o varios acreedores, preferentes o no, con posposición del resto”, depende de que se haya admitido a trámite la solicitud de quiebra, concurso o suspensión de pagos, no se haya obtenido la preceptiva autorización judicial o de los órganos concursales y no se trate de uno de los casos permitidos por la ley.

En la declaración de hechos probados de la Sentencia recurrida consta que el primero de los recurrentes, Francisco G. M., retiró del Banco donde tenía depositado su patrimonio en efectivo, mediante órdenes y autorizaciones que cursó a sus hermanas, un total de 2.443 .476 pesetas que le pertenecían, con las que aquéllas hicieron frente, encontrándose Francisco en prisión, a "gastos corrientes" de la casa familiar por importe de 616.093 pesetas y al pago de los honorarios de peritos, abogados y procuradores que le prestaron servicios profesionales en el procedimiento penal que al mismo se le seguía, por una cantidad ascendente a 1.597.140 pesetas. Este destino que dieron las hermanas de Francisco, de acuerdo con sus instrucciones, al dinero obtenido con los reintegros bancarios, impidió ciertamente que se asegurasen sus responsabilidades civiles, calculadas en diez millones de pesetas, mediante el embargo de su cuenta de ahorros acordado en la correspondiente pieza separada del mencionado procedimiento. Pero fácilmente se advierte que lo hecho por el acusado, mediante las operaciones por las que ha sido condenado, no fue en definitiva sino reservar la mayor parte de su patrimonio en efectivo para el pago de deudas reales preexistentes - los llamados gastos corrientes - y para la atención de las que habian de nacer, casi con toda seguridad, de la necesidad de defender sus intereses de acusado en aquel procedimiento. Prescindiendo, pues, de la no relevante cantidad que resulta de restar del dinero dispuesto por las hermanas del acusado el invertido en el pago de otras obligaciones — cantidad insuficiente para deducir de ella ánimo defraudatorio- lo que del factum de la Sentencia recurrida se desprende no es una conducta orientada a ocultar o hacer desaparecer el patrimonio para burlar los derechos de los acreedores, sino otra muy distinta inspirada por la decisión, vista la insuficiencia del caudal disponible, de otorgar preferencia a unos créditos, ya existentes o de segura aparición, sobre otros. Como quiera que esta conducta, según ya 
hemos razonado, no es subsumible en el art. 258 CP por no revestir los caracteres del delito de alzamiento de bienes, cuya definición doctrinal no puede dejar de ser tenida en cuenta en la interpretación de aquel precepto, debemos estimar el tercer motivo del recurso y declarar efectivamente infringida dicha norma penal por aplicación indebida. Desaparecido el delito, es claro que no tiene sentido, por superfluo, entrar a examinar los recursos en que se cuestiona la responsabilidad penal de las otras dos acusadas, condenadas en la Sentencia de instancia por su cooperación en el supuesto delito, por lo que procede, sin más razonamientos, la estimación de dichos recursos juntamente con el que ha sido objeto de nuestra fundamentación y el pronunciamiento de una segunda Sentencia más conforme a derecho».

\subsection{Favorecimiento de acreedores (art. 259)}

—STS (Sala de lo Penal), de 28.04.2003:

«Fundamentos de Derecho. Primero. - La AP de Barcelona condenó a los acusados como autores responsables de un delito de insolvencia punible previsto y penado en el art. 260 CP (RCL $1995 \backslash 3170$ y RCL 1996, 777).

Los hechos de que traen causa la mencionada calificación jurídica y el subsiguiente pronunciamiento condenatorio, consisten, sustancialmente, en que los ahora recurrentes eran administradores solidarios de la entidad mercantil "Distribuciones Coalco, S.A.", que presentaba una situación solvente hasta el día 30 de abril de 1994 según el balance de esta fecha. No obstante, en 8 de julio de 1994, la empresa presentó solicitud de quiebra, aportando un balance de situación de la sociedad a dicha fecha que presentaba un déficit de 21.219 .000 ptas., declarándose la misma por Auto de 13 de julio por el Juzgado de Primera Instancia $N^{\circ} 3$ de los de Barcelona, retrotrayéndose los efectos de la misma al día 11 de abril de 1994.

El dato fáctico esencial en el que se base la sentencia condenatoria y que a juicio del Tribunal de instancia constituye la acción típica sancionada en el art. 260 CP, consiste, según el factum, en que en el período comprendido entre el 1 de mayo y el 8 de julio de 1994, los acusados “... acordaron cobrar parte de los créditos de los que eran acreedores frente a la sociedad, extrayendo de las cuentas sociales, según los balances de situación, la cantidad de 15.498 .000 ptas. que se incorporó al patrimonio de Romeo, con la aquiescencia de Alejandro, ocasionando un perjuicio a la masa de acreedores por importe de aquella cantidad detraída”.

Segundo.- Sin necesidad de entrar en el análisis de los otros motivos en los que se alega que, en cualquier caso, los acusados habrían actuado con error de tipo y/o de prohibición que excluiría el dolo como elemento esencial constitutivo de la figura delictiva, el reproche debe 
ser estimado. En efecto, la sentencia establece que los acusados, al margen de ser los coadministradores de la entidad, eran titulares de unos derechos de crédito contra aquélla, al igual que otros acreedores de la empresa, y que al entrar ésta en período de crisis económica, hicieron efectivos dichos créditos, lo que, naturalmente, provocó una disminución del activo de la sociedad y la consiguiente negativa repercusión en las expectativas de los demás acreedores a percibir sus créditos.

Cabe señalar que la sentencia recurrida circunscribe a esta conducta la acción penalmente sancionada en el art. 260 CP, al destacar que de ese modo se actuó... con perjuicio de los acreedores, al disminuir considerablemente el activo y en consecuencia alterando el principio de pago ordenado y de igualdad de pérdidas" (fundamento de derecho Quinto). Sin embargo, tratándose del ejercicio legítimo de un derecho no cabe reputar que esta conducta sea constitutiva de la acción maliciosa y fraudulenta que constituye el núcleo del delito previsto en el art. 260, y, en el supuesto de autos, concretado en agravar dolosamente la situación de crisis económica de la empresa, ya que la disminución del activo de ésta es inexorable consecuencia de cumplir la obligación previamente adquirida con los acreedores que hacen efectivo su derecho crediticio, resultado que hubiera sido el mismo de ser cualquiera otro acreedor el que hubiese ejercitado su derecho.

En realidad, lo que expresa el relato histórico es que la única actividad de los acusados susceptible de relevancia en el orden penal es - como se destaca en la fundamentación jurídica de la sentencia-la quiebra del régimen de prelación de créditos y la eventual vulneración de los principios de pago ordenado de la masa de acreedores de la entidad concursada, y así lo expone razonadamente el Fiscal, añadiendo que la tipificación del artículo 259 revela que a sensu contrario son impunes también en la quiebra del art. 260 CP las alteraciones de la preferencia de créditos anteriores a la admisión a trámite del procedimiento concursal sin perjuicio de su ilicitud jurídico-mercantil y de los efectos de la retroacción.

Siendo un hecho probado que el pago de los créditos de que eran titulares los acusados se realizó con anterioridad a la solicitud de declaración de quiebra voluntaria, tampoco podría ser aplicable el art. 259 CP toda vez que el tipo exige que junto a la realización de "cualquier acto de disposición patrimonial o generador de obligaciones destinado a pagar a uno o varios acreedores, preferentes o no, con posposición del resto", tal actuación ha de llevarse a cabo "una vez admitida a trámite la solicitud de quiebra, concurso o suspensión de pagos...”, requisito éste que no concurre en el caso de autos y que - al margen del principio acusatorio - impide la incardinación de los hechos en el referido tipo penal. La estimación del motivo exime del examen del resto y, en consecuencia, procede casar la sentencia de instancia dictándose otra nueva por esta Sala con pronunciamiento absolutorio de los acusados». 
3.5. Insolvencia causada o agravada por el deudor (art. 260)

—STS (Sala de lo Penal), de 15.12.1997:

«Fundamentos de Derecho. Noveno. El motivo primero, con apoyo en el $n .{ }^{\circ} 1 .^{\circ}$ del art. 849 LECr., alega la inobservancia del art. 260.1 y 2 del vigente Código Penal, al producirse un error de derecho en la aplicación de tal artículo (sic). Luego señala que no se dan en el recurrente los requisitos de tal precepto. El inatacable factum describe la constitución por el ahora recurrente y el coacusado en Madrid de una sociedad H. L., S.A., con un capital social de veinticinco millones de pesetas, fijando el domicilio social en Llodio y la finalidad la adquisición de la planta embotelladora de Vinícola Internacional, S.A. (conocida como "Bodegas A.") adquiriendo los activos de ésta por diez millones de pesetas, y haciéndose cargo de 103 trabajadores de la plantilla de esta sociedad. Tanto el recurrente como el coacusado asumieron la gestión directa de dicha empresa.

El 19 de septiembre de 1985, ambos acusados y el gerente entonces de H. L., S.A., constituyen Bodegas O., entidad con el mismo domicilio que la otra y con un capital de un millón de pesetas. En junio siguiente el gerente vendió sus doscientas acciones a los acusados que se convierten en titulares del cien por cien del capital social de esta nueva entidad, de la que no figuran trabajadores, no está dada de alta en la Seguridad Social, ni siquiera en la Compañía Telefónica. Se constituye el 14 de enero de 1986 una póliza de crédito de cuenta corriente con garantía personal por veinticinco millones de pesetas en favor de Bodegas R.A., S.A., y presta garantía solidaria H.L., S.A. Tal operación se realiza con la Caja de Ahorros Municipal de Bilbao. El 5 de marzo siguiente se constituye una póliza de garantía con la misma entidad que avala siete cambiales por un importe de 7.277.995 de pesetas, letras que son giradas y aceptadas por Bodegas R.A., S.A., afirmando tal operación solidariamente H.L., S.A., figurando en representación de la primera el recurrente y de la otra el coacusado $S$. El 29 de noviembre siguiente H.L., S.A., reconoce adeudar a Bodegas O., S.A., 120.000.000 de pesetas y se constituye en garantía de tal deuda hipotecas y prenda, interviniendo por H.L., S.A., ambos acusados y S. por Bodegas O. El 3 de febrero de 1987 Bodegas O., S.A., fue vendida a Cosecheros R., S.A., con transmisión de la citada garantía hipotecaria. Pero ya, a finales de 1986, se retrasa H.L., S.A., en el pago de las nóminas, deja de abonar el veinte por ciento de la paga extraordinaria y no se paga la nómina de enero de 1987 hasta el punto de iniciar los trabajadores una huelga, ocupando la fábrica. H. L. comunica a la autoridad administrativa el cierre patronal. Cuando surgen problemas con los trabajadores sobre la reapertura. El Letrado de la empresa indica que ésta debe 100.000 .000 de pesetas a distintos acreedores y tienen una hipoteca de 120.000 .000 de pesetas y de 55.000.000 de pesetas más a entidades públicas.

La quiebra necesaria es instada por los Bancos A., Financiación I., H.A., Z. y G., declarándose así por auto de 19 de agosto de 1987 a la 
Sociedad H.L., S.A., y retrotrayéndose la quiebra al 1 de enero de 1986. El día 2 de junio de 1989 se dictó sentencia por el JPI n. ${ }^{\circ} 1$ de Bilbao calificando la quiebra de fraudulenta... No cabe duda de que se trata en el sentido mercantil de una quiebra fraudulenta, la más grave de las así calificadas en la práctica comercial, que ahora en la nueva tipicidad del precepto se comete con un presupuesto de la declaración de quiebra y cuya insolvencia ha sido causada o agravada dolosamente por el deudor. Mas ello concurre indudablemente en este supuesto y para evitar repeticiones, esta Sala acepta las razones del fundamento jurídico de la resolución recurrida, así como la cuantía del perjuicio, el número de afectados y su condición económica. Las actuaciones realizadas en la póliza en favor de Bodegas R.A., S.A., y su cobertura hipotecaria e inmobiliaria sin justificación a deudas anteriores y con ausencia de los asientos contables al respecto, agravaron intencional, maliciosa y voluntariamente la crisis económica de la empresa. El delito es paradigma del art. 260 aducido y por ello el motivo debe ser desestimado».

—STS (Sala de lo Penal), de 19.10.1998:

«Fundamentos de Derecho. Primero. El Tribunal de instancia, en el primero de los fundamentos jurídicos de la sentencia impugnada, razona sobre las pruebas que ha tenido en cuenta para alcanzar la convicción fáctica que se contiene en los hechos que se declaran probados. $Y$ señala no sólo los informes elaborados por los síndicos de la quiebra, sino también la documental remitida por los Registros de la Propiedad, por entidades bancarias y Juzgados. De todas ellas se evidencia el deterioro patrimonial que ha resultado patentemente agravado por las operaciones que se describen en el relato histórico de la sentencia y en las que se incluyen hipotecas a favor de un cuñado por préstamos inexistentes, reconocimientos de créditos ficticios, constitución de hipotecas que no aparecen en la contabilidad, arrendamientos de locales a sociedad representada por su esposa, por precios inferiores al de mercado, transferencias de importantes sumas de dinero a sociedad familiar, sin justificación contable, transferencias a cuenta abierta por su hijo y también acusado Daniel S.G. que superan los veintiocho millones de pesetas sin que aparezca en la contabilidad apunte que las justifique, inexistencia de un efectivo "en caja” por importe de 33.251.126 pesetas, y ello unido a inexactitudes en el balance, deficiencias en la contabilidad, falta de legalización en los libros y, en definitiva, el uso por el quebrado de mecanismos contables para distraer fondos de la empresa, que en modo alguno se ven desvirtuadas por las referencias documentales que se alegan en defensa del presente motivo. No ha existido, pues, el error en la apreciación de la prueba que se denuncia.

Tercero. Se alega, pues, la incongruencia omisiva en que ha podido incurrir la sentencia; y es doctrina reiterada de esta Sala que el expresado motivo del recurso de casación presupone el silenciar o no dar 
respuesta, positiva o negativa, explícita o implícita, a algún pedimento o pretensión jurídica formulada por las partes en sus calificaciones definitivas. $Y$ en el caso que examinamos, no concurre ninguno de los presupuestos que se dejan mencionados ya que el que se dice quebrantamiento de forma se contrae a que se hubiera omitido en la sentencia que el recurrente había devuelto a "Hispavox" material por importe de unos 50 millones de pesetas y que eso eliminaría el tipo subjetivo, por ausencia de dolo, del delito por el que viene condenado. La omisión que se aduce no recae sobre pretensiones jurídicas o cuestiones de derecho que afecten al acusado que las invoca. Se trata de una cuestión fáctica que no ha quedado acreditada y por ello no se refleja en el relato de hechos probados, sin que el Tribunal deba pronunciarse, puntual y específicamente sobre cada uno de los extremos alegados que puedan incidir en la contabilidad examinada. De lo que no cabe duda es que el Tribunal sentenciador ha hecho pronunciamiento expreso sobre los elementos que caracterizan el tipo objetivo y subjetivo de la figura delictiva objeto de acusación, y respecto a este último sobre el claro propósito de perjudicar a los acreedores provocando su situación de insolvencia, mencionando las contabilidades difusas, las simulaciones, las ocultaciones maliciosas de efectos, mediante las cuales el quebrado empeoró y agravó voluntariamente su situación financiera, con la finalidad de dejar vacío su patrimonio y, con ello, defraudar a sus acreedores.

Sin la debida cobertura procesal que le sirva de apoyo, se menciona en este mismo motivo la improcedencia de la condena al hijo Daniel S.G., cuando éste, según el motivo, se limita a abrir una cuenta a petición de su padre y a firmar lo que su padre le pedia, por lo que ante la ausencia absoluta de dolo en su comportamiento no puede ser constitutivo de delito.

El Tribunal sentenciador dedica el último párrafo del tercero de los fundamentos jurídicos, a la responsabilidad, como cómplice, del acusado Daniel S.G., y razonablemente alcanza la convicción de que conocía que con su aporte estaba ayudando a su padre y coacusado a ocultar bienes, disminuyéndose el patrimonio en perjuicio de sus acreedores. $Y$ ciertamente no puede alegarse desconocimiento cuando se ingresaron en una cuenta abierta a su nombre más de veintiocho millones de pesetas transferidos desde cuentas de la empresa, así como su participación en otras operaciones, siendo nombrado administrador único de "Vídeo Campo, SA", en sustitución de su padre. Por todo ello es conforme con las reglas de la lógica y la experiencia la inferencia alcanzada por el Tribunal sentenciador de que el hijo conocía la situación económica de la empresa y la ocultación y evasión de dinero que se buscaba con las importantes transferencias efectuadas a una cuenta abierta a su nombre. Este extremo del motivo tampoco puede ser estimado al ser correcta la calificación jurídica realizada por el Tribunal sentenciador sobre la participación de Daniel S.G. en los hechos enjuiciados». 
—STS (Sala de lo Penal), de 6.04.1999:

«Fundamentos de Derecho. Segundo. En el motivo 1. ${ }^{\circ}$, al amparo del núm. $3{ }^{\circ}$ del art. 851 LECr., se alega incongruencia omisiva porque, se dice, no se resolvió en la sentencia sobre uno de los extremos por los que se mantuvo la acusación: la aplicación de más de ocho millones de pesetas del capital de la sociedad quebrada "Núrbel Service, SA", que administraba don José María R. B., que, sin soporte contable alguno, aparecen invertidos en viajes y asistencias a reuniones cuando la actividad de la empresa estaba tocando a su fin.

La sentencia fue absolutoria con lo cual, evidentemente, fueron resueltos todos los extremos por los que la acusación se vino formulando: es claro que con tal pronunciamiento quedaban rechazadas todas las pretensiones acusatorias de la parte querellante. Pero es que, además, como bien pone de relieve el escrito de contestación al recurso hecho por la defensa del acusado, la sentencia recurrida se refiere en su texto al mencionado extremo englobado en los diferentes gastos pretendidamente injustificados a los que expresamente se refiere el apartado $C$ ) del fundamento de derecho primero. Como bien dice el último párrafo del mencionado fundamento de derecho $1 .^{\circ}$ la absolución se funda en que la acusación particular, única existente, no probó «en forma alguna los términos en que se fundaba» uno de los cuales era precisamente el relativo a los mencionados 8 millones de gastos en viajes y participación en reuniones, a los que se refiere el punto 4 del párrafo 2 de tal fundamento de derecho 1. ${ }^{o}$, y a lo que se contesta, englobado con lo relativo al punto 3 , en el mencionado apartado $C$ ). Son los pagos y gastos a los que alude, casi al final, el párrafo relativo a los hechos probados, cuando nos dice que no fue acreditado que se realizaran (esos pagos o gastos) careciendo de justificación jurídica, añadiendo después que la empresa quebrada tenía debidamente regularizada la contabilidad.

Tercero. En el motivo 2. ${ }^{\circ}$, con base en el núm. 1. ${ }^{o}$ del art. 849 LECr., se alega error de derecho por no haberse calificado los hechos enjuiciados como delito de quiebra fraudulenta del art. 260.1 CP, constando como probados los diferentes requisitos que configuran este delito. Ciertamente no hubo tal error de derecho, porque los hechos probados de la sentencia recurrida, dejan claro con evidencia plena que, de todo aquello por lo que se mantuvo la acusación, lo único que quedó acreditado fue que existió una declaración de quiebra voluntaria, a solicitud del acusado en calidad de administrador único de la sociedad quebrada, pero sin que llegara a probarse ninguno de los extremos de hecho en los que la parte querellante venía fundando su acusación de quiebra fraudulenta. Tal inexistencia de prueba, que aparece luego razonada en su fundamento de derecho $1 .^{\circ}$, impide claramente la aplicación al caso del referido art. 260.1 del Código Penal. Claro es que podemos considerar incluidos en los hechos probados aquellos extremos que pudieran aparecer como admitidos por la Sala de instancia en los fundamentos de dere- 
cho. Pero es que tampoco hay en éstos afirmaciones fácticas que pudieran servir de apoyo para una condena. Se dice y repite en ese fundamento de derecho $1 .^{\circ}$ que no hubo prueba de aquello por lo que se acusó y no cabe entresacar de su texto nada que pudiera servir como base para la pretendida condena.

En el desarrollo de este motivo se hacen alegaciones sobre las diversas pruebas practicadas, alegaciones que son propias de la instancia para convencer a la Audiencia de la forma en que pudieron ocurrir los hechos, pero que carecen de toda posibilidad de éxito en este recurso extraordinario que ha de respetar la valoración que de la prueba se hizo en la sentencia recurrida, lo que, por otro lado, no se puede atacar por la vía procesal aquí elegida, la del art. 849.1. ${ }^{\circ}$ LECr., que obliga a quien recurre a respetar los hechos declarados probados (art. 884.3. ${ }^{\circ}$ de tal Ley Procesal)».

—STS (Sala de lo Penal), de 16.07.1999:

«Fundamentos de Derecho. Segundo. Ya en la sentencia del recurso de casación que contra la sentencia de instancia se interpuso, se realizan amplias explicaciones sobre las similitudes entre el tipo penal aplicado en el caso y el nuevamente introducido en el artículo 260, sin olvidar una referencia a la improcedencia en materia penal de la presunción «contra reo» de considerarse en el artículo 889.1. ${ }^{\circ}$ del Código de Comercio quiebra culpable la no llevanza de libros de contabilidad, que no ha pasado al nuevo Código Penal, en cuya redacción actual se cierra el paso a cualquier efecto penal de la calificación de la insolvencia en el proceso civil, según el número 4 del artículo 260 del nuevo Código.

Pese a que en los hechos probados de la sentencia de instancia se dice que la empresa del recurrente no llevaba contabilidad, de ello no se deduce ninguna razón para su condena, ni se hace uso de un tipo penal que se remitía para completarse a otras normas. En los hechos probados se recoge que el actual recurrente junto con otro acusado, con el fin de que los acreedores de la sociedad EVISA no pudieran encontrar dinerario con que cobrar sus créditos, procedieron a endosar los créditos que la sociedad tenía contra sus deudores a la empresa "Técnica de Estudios de Calefacción y Fontanería, SA”, sin que tales endosos correspondieran a reales operaciones entre ambas sociedades. Y es que desde la Ley Orgánica 8/1983, las acciones u omisiones en que los delitos consisten, dejaron de presumirse voluntarias para establecerse que debían responder a dolo o culpa para ser delito, por lo cual en la Sentencia dictada en la instancia en 15 de febrero de 1996, aunque se hacen referencia a los artículos del Código de Comercio que completaban el tipo del artículo 520 del Código Penal ya hoy derogado, se explica y valora la conducta de endosos injustificados de los créditos de EVISA con el fin de impedir a sus acreedores cobrar los créditos que contra ella tenían, actividad que se calificó entonces de quiebra frau- 
dulenta y, ahora, cuando se ha procedido a aplicar el nuevo Código Penal al recurrente, respetando los hechos de aquella sentencia como es preceptivo, encajan, aún más adecuadamente si cabe, en la nueva dicción del artículo 260 cuando exige que la situación de crisis o de insolvencia en la quiebra sea causada o agravada dolosamente. Esa es precisamente la conducta que en los hechos probados de la sentencia se atribuye al recurrente, por lo cual el motivo ha de decaer.

Tercero. Ya se afirmó en la sentencia de casación recaída en esta causa que la inclusión en el Texto Legal del artículo 31 del administrador de hecho no excluye la del que administre de derecho la entidad jurídica en cuestión. El mismo Texto Legal citado, inmediatamente después del administrador de hecho añade "o de derecho". La sentencia dictada en la instancia dice, en efecto en los fundamentos jurídicos que el coencausado Rafael $S$. era quien tomaba decisiones, pero tal afirmación no excluye la del actual recurrente, del cual, en el relato de hechos probados, se dice que actuó endosando créditos de EVISA a la otra empresa que dirigía el citado coencausado, con el fin de que los acreedores de la sociedad de la que era gerente no pudieran encontrar dinerario con el que cobrar sus créditos. En definitiva, la nueva redacción del Código Penal en su artículo 31 que incluye al administrador de hecho no excluye al que lo sea de derecho, como lo era el recurrente y su condena procedía y se dictó en razón de la conducta dolosa descapitalizadora de su empresa provocadora de la quiebra de la misma, y que no cambia en modo alguno tal carácter en razón de la dicha innovación legislativa».

—STS (Sala de lo Penal), de 28.01.2000:

«Fundamentos de Derecho. Tercero. En el segundo motivo del recurso se denuncia la infracción del artículo 260.2 del Código Penal, que ha incluido tres nuevas circunstancias para graduar la pena: la cuantía del perjuicio inferido a los acreedores, su número y su condición económica.

La Sentencia del Tribunal Constitucional de 2 de marzo de 1998 dice que "los datos básicos del proceso de individualización de la pena han de inferirse de los hechos probados, sin que sea constitucionalmente exigible ningún ulterior razonamiento que los traduzca en una cuantificación de pena exacta, dada la imposibilidad de sentar un criterio que mida lo que, de suyo, no es susceptible de medición”.

En el caso ahora examinado, consta en la Sentencia que el perjuicio causado a los acreedores supera los treinta y un millones de pesetas, por lo que en modo alguno puede entenderse que la pena impuesta - tres años de prisión- resulta irrazonable o contraria al artículo 260.2 del vigente Código Penal. Sin que ello se vea desvirtuado por las actuaciones practicadas en orden al aseguramiento de las responsabilidades civiles de la acusada, ya que el perjuicio inferido a los acreedores es el que se recoge en la Sentencia, que podrá ser o no ser objeto 
de posterior reparación o indemnización en fase de ejecución de la misma. En consecuencia, también el segundo motivo del recurso debe ser desestimado».

—STS (Sala de lo Penal), de 2.01.2003:

«Fundamentos de Derecho: Primero. El condenado en la instancia formula un primer motivo de casación al amparo del art. 849.1. ${ }^{\circ}$ LECrim (LEG 1882\16), por infracción de ley, denunciando la indebida aplicación del art. 260 CP. Como fundamento del reproche casacional se alega que no consta como hecho probado que fuese el acusado quien dirigiera la administración de la empresa, ni que, con su conducta, encauzara a ésta hacia una situación de quiebra, como tampoco consta acreditado, ni se han cuantificado perjuicios a los acreedores ni que los gastos hayan revertido en beneficio propio o de algún acreedor en particular en perjuicio de los restantes. Sostiene también el recurrente que los gastos efectuados por el acusado no tuvieron incidencia en la aparición de la quiebra o en el agravamiento de la misma y que el Tribunal a quo no toma en cuenta el activo de la empresa ni la situación financiera de ésta, limitándose a reproducir los datos del proceso civil.

Como todo motivo de casación que se encauza por el art. $849.1 .^{\circ}$ de la Ley Procesal, habrá de estarse al contenido estricto de la declaración de Hechos Probados y, desde el más riguroso respeto a los datos allí consignados, la censura debe ser desestimada por los mismos fundamentos que aduce el Ministerio Fiscal al impugnar el motivo. En efecto, como bien argumenta el Fiscal al impugnar el motivo el factum precisa que el recurrente era administrador solidario de la empresa y en tal condición realizó las acciones reprochadas, suficientemente individualizadas, consistentes en distraer en los días previos a la solicitud de quiebra, 2.295.000 ptas., un ordenador y la maquinaria y efectos descritos en el relato histórico sustrayéndolos así al inminente procedimiento concursal que él mismo instó en nombre de la entidad. Estos comportamientos agravaron la situación de quiebra como se razona en el F. 2, en cuanto que tales bienes dejaron de constituir activos de la sociedad y empeoraron por tanto la situación de insolvencia que padecía, siendo indiferente a efectos de la subsunción en el tipo del art. 260 el destino final de los mismos. Existe relación causal entre los actos realizados y el resultado de agravación de la mencionada insolvencia que es lo que reprocha la sentencia. Los jueces a quibus no imputan su causación sino como se dice la agravación que es el resultado alternativo típico del art. 260 CP». Por otra parte, es patente que la figura delictiva en que se incardina la actividad del acusado, no exige determinar o individualizar el perjuicio causado a los acreedores que no forma parte de la estructura típica sino que - como explícitamente indica el núm. 2 del precepto-es un elemento que juega a los meros efectos de graduación de la pena. 
El relato histórico y las consideraciones que el Tribunal a quo sienta es la fundamentación jurídica de la sentencia reflejan una situación de insolvencia de la empresa administrada por el acusado que se agudizó por la conducta de éste, que mermó la masa de la quiebra agravando la crisis económica de la entidad con el correlativo perjuicio para los acreedores colectivamente considerados; conducta que debe ser consciente e intencionadamente ejecutada como acaece en el caso actual según razona la sentencia, pues, de una parte, el acusado extrajo de las cuentas de la sociedad más de dos millones tan sólo una semana antes de presentar la solicitud de quiebra voluntaria, sin que haya explicado el destino dado a dicho numerario, y de otra, ocultó determinados bienes a la masa de la quiebra mediante su traslado a una nave de cuya existencia nada se dijo al Juzgado, denunciando la desaparición de bienes sin que tampoco se comunicara nada al Juzgado sobre su recuperación y depósito en dicha nave. Y todo ello sucedió con anterioridad a la presentación de la solicitud de quiebra voluntaria pero con la evidente finalidad de dejar fuera de dicho procedimiento de ejecución colectiva a dichos bienes y efectos, reduciendo así consciente y voluntariamente la futura masa de la quiebra. Y no puede entenderse justificado el reintegro de dinero de las cuentas societarias para el pago de gastos generados por la actividad empresarial, primero, por no haberse acreditado ni siquiera mínimamente la inversión en tales gastos, y segundo, por la poderosa razón de que todos los trabajadores de la empresa que han depuesto como testigos manifestaron que en las semanas anteriores a la presentación de solicitud de quiebra ya no se cobraban ni los sueldos ni las dietas. En cuanto a la ocultación de bienes en la nave de Villalbilla ninguna explicación coherente se ha dado sobre tal extremo por Julio C. M. que, de forma maliciosa, consintió que la diligencia de ocupación de bienes del quebrado se hiciera en otra nave de la que previamente se había sacado maquinaria, y también de forma consciente y voluntaria, se silenció la existencia de la nave de Villalbilla cuya llave poseía dicho acusado ya que fue él la persona que la entregó cuando se descubrió su existencia el día 1 de agosto de 1996.

Segundo. El segundo motivo, amparado en el art. 849.2. ${ }^{\circ}$ LECrim (LEG 1882\16), pretende la exclusión de la condena por responsabilidades civiles del valor de los bienes reseñados en el epígrafe d) de los Hechos Probados. El motivo cuenta con el explícito y fundado apoyo del Ministerio Fiscal y debe ser estimado. Así, y con independencia de que tales bienes y efectos fueran trasladados por el acusado en fecha no determinada pero anterior en una o dos semanas a la presentación en el Juzgado de la solicitud de quiebra voluntaria desde la nave donde se encontraban a otra sita en Villalbilla, tal y como consta en el factum, lo cierto es que con posterioridad a dicho subrepticio traslado, esos mismos bienes fueron intervenidos en Villalbilla por la comisión judicial según Acta de fecha 1 de agosto de 1996 que obra al folio 122 de las actuaciones y que invoca el recurrente donde se hace constar que se 
ponen a disposición de los Síndicos de la quiebra, designándose depositario de aquéllos al señor B. S., que acepta tal designación; hecho que se ratifica por la certificación emitida por el Comisario de la quiebra obrante al folio 140 y que también señala el motivo. En definitiva, dichos documentos acreditan que los bienes a que se refiere el motivo fueron incorporados a la masa de la quiebra tras su intervención judicial y ocupados por los Síndicos para hacer frente a las obligaciones de la empresa quebrada y, por ello, no deben ser incluidos en el pronunciamiento indemnizatorio».

\section{—STS (Sala de lo Penal), de 8.10.2003:}

«Fundamentos de Derecho. Primero. El primer motivo del recurso interpuesto por la representación de D. Esteban, por infracción de ley al amparo del art. 849.1. ${ }^{\circ}$ de la LECrim (LEG 1882, 16), alega aplicación indebida del art. 260 del Código Penal de 1995 (RCL 1995, 3170 y RCL 1996, 777), por estimar el recurrente que en los hechos declarados probados no concurren los elementos del delito de quiebra dolosa por el que ha sido castigado. Alega el recurrente que no se ha concretado el perjuicio para la masa de acreedores, únicamente se indemniza a un acreedor, la sentencia toma en consideración un balance elaborado con anterioridad en una previa suspensión de pagos, y no se concreta el modo en que se ha producido el vaciamiento patrimonial de la sociedad.

El cauce casacional empleado implica el respeto del relato fáctico. En éste consta que los condenados, administrador y socio único de una sociedad que adquirieron en suspensión de pagos, pero que tenía un activo importante, lejos de promover la continuidad de la empresa, para lo que supuestamente la habían adquirido, procedieron a su vaciamiento patrimonial, en su propio beneficio, cerraron la sede de la misma, hicieron desaparecer los libros y la documentación, e impidieron a los doscientos acreedores de la sociedad la realización de sus créditos, provocando la quiebra. En el relato fáctico consta que el activo de la empresa cuando fue declarada en suspensión de pagos era superior a doscientos sesenta y seis millones de pesetas, y que los acusados, en cuanto se hicieron cargo de la misma y en su propio beneficio, hicieron desaparecer todos los activos a excepción de algunos bienes valorados en menos de catorce millones de pesetas, al mismo tiempo que ocultaban la totalidad de los libros, provocando finalmente que se declarase civilmente la quiebra fraudulenta. En consecuencia concurren todos los elementos del tipo definido en el art. 260, pues los acusados provocaron dolosamente la insolvencia, siendo procedente la desestimación del motivo.

Segundo. Las alegaciones del recurrente son irrelevantes para la subsunción. El perjuicio para la masa de acreedores consta en el procedimiento de quiebra sin que sea imprescindible para la sanción de la conducta delictiva su exacta cuantificación en el proceso penal. El hecho de que únicamente se declare la responsabilidad civil derivada del delito en beneficio de un acreedor es consecuencia de que en este ámbi- 
to penal únicamente puede otorgarse indemnización cuando se haya solicitado expresamente y el acreedor indemnizado es el que ha ejercitado la acusación particular. La sentencia toma en consideración el balance elaborado con anterioridad en la suspensión de pagos precisamente por ser demostrativo de que existía un activo importante que los acusados han malbaratado. En cuanto al modo en que se ha producido el vaciamiento patrimonial de la sociedad los acusados se han ocupado de ocultarlo, haciendo desaparecer todos los libros e incluso cerrando la sede social y desapareciendo del lugar, pero consta suficientemente que los acusados han hecho desaparecer prácticamente todos los activos.

Tercero. El segundo motivo, también por infracción de ley, denuncia la supuesta infracción del art. 28 del Código Penal de 1995 (RCL 1995, 3170 y RCL 1996, 777) por no concurrir en el acusado los requisitos de la condición de autor. El cauce casacional impone el respeto del relato fáctico. En éste se incluye al recurrente como realizador conjunto de los actos descapitalizadores de la sociedad que provocaron dolosamente la quiebra. La definición de la coautoría acogida en el art. 28 del Código Penal de 1995 como "realización conjunta del hecho" implica que cada uno de los concertados para ejecutar el delito colabora con alguna aportación objetiva y causal, eficazmente dirigida a la consecución del fin conjunto. No es, por ello, necesario que cada coautor ejecute, por sí mismo, todos los actos materiales integradores del tipo, pues a la realización del delito se llega conjuntamente, por la agregación de las diversas aportaciones de los coautores, integradas en el plan común, siempre que se trate de aportaciones causales decisivas. Y en el caso actual constando que el recurrente se prestó a adquirir la totalidad de las acciones de la empresa, y en consecuencia era quien controlaba lo que en ella pudiese realizar el coacusado, es claro que su aportación causal resultó decisiva.

Cuarto. El cuarto motivo alega presunción de inocencia. Imputa el recurrente la responsabilidad de los hechos a su suegro, un abogado ya fallecido, alegando que fue quien diseñó y organizó la operación. La invocación del derecho a la presunción de inocencia supone en trance casacional la comprobación de que en la causa exista prueba de signo incriminatorio o de cargo que pueda razonablemente ser calificada como suficiente, sin que proceda, como pretende la parte recurrente, efectuar un análisis minucioso y detallado de la resultancia probatoria suplantando al Tribunal sentenciador.

En el caso actual la prueba es contundente e irrefutable. La participación personal y directa del recurrente en la operación se encuentra documentalmente acreditada, pues fue el adquirente de las acciones $y$, como tal, quien asumía la condición de deudor y la obligación de respetar la suspensión de pagos y no aprovecharse del activo de la empresa, llevándola a la quiebra. Los indicios de la naturaleza dolosa de su acción son irrebatibles: la desaparición de los libros, la desaparición de la sede, la desaparición de los bienes, etc. El recurrente, mayor de edad, 
tenía necesariamente que conocer que al adquirir la empresa por una peseta estaba asimismo asumiendo una serie de obligaciones. Sabía, también, que participaba de modo necesario en una determinada operación, en la que su condición de propietario de las acciones era absolutamente relevante. En consecuencia, al prestarse a todo ello estaba colaborando con una aportación objetiva, decisiva y causal, eficazmente dirigida a la consecución del fin conjunto. Su condición de coautor es manifiesta. El motivo, en consecuencia, debe ser desestimado».

—STS (Sala de lo Penal), de 2.04.2004:

«Fundamentos de Derecho. Octavo. - En el noveno de los motivos denuncia el error de derecho por la indebida aplicación del art. 260 del Código Penal (RCL $1995 \backslash 3170$ y RCL 1996, 777) al entender que desde el relato fáctico (JUR 2001\325572) no resulta incompatible la voluntad de los acusados de enjuagar las deudas que pudiera tener Internacional Casting mediante la creación de la nueva Gis Corporation. El motivo se desestima. Desde el respeto al hecho declarado probado lo que resulta es que los acusados realizaron con el patrimonio de la sociedad gastos suntuarios que se concretan en la realización de gastos personales a cuenta de la sociedad, en la utilización de la tarjeta de la empresa para gastos personales, como viajes, compra de materiales, etc., y en la utilización de un trabajador de la empresa para trabajar en la vivienda particular. La existencia de deudas que hacían inviable la continuación de la empresa determinó la constitución de una nueva empresa, con parte de los trabajadores, maquinaria y clientes de la antigua, hundiendo económicamente a la anterior que se vio abocada a la quiebra. La ausencia de una contabilidad que reflejara los gastos de la sociedad permite la declaración que el tribunal realiza sobre la realización dolosa de los acusados en la crisis de la empresa».

\subsection{Falsedad contable (art. 261)}

—STS (Sala de lo Penal), de 19.01.1998:

«Fundamentos de Derecho. Segundo. La supuesta despenalización de la falta de contabilidad. Efectivamente en el antiguo Código Penal (artículos 523 y 524) se verificaba una remisión a los artículos 888 a 890, ambos incluidos del Código de Comercio, regulando los distintos supuestos de quiebra culpable y de insolvencia fraudulenta. No menos cierto es que el Nuevo Código Penal en sus artículos 257 al 262 no contiene esa remisión normativa, así como tampoco distingue entre quiebra fraudulenta culpable. Sin embargo, de tales datos no puede extraerse la consecuencia que los recurrentes en su adaptación de los motivos al NCP pretenden. En efecto las Leyes penales "en blanco", conforme a la jurisprudencia constitucional (SSTC 127/1990, fundamento jurídico $\left.3 .^{\circ} . \mathrm{B}\right)$, y 118/1992), fundamento jurídico $2 .^{\circ}$ ) indica que 
la exigencia del principio de legalidad no suponen que sólo resulte constitucionalmente admisible la redacción descriptiva y acabada en la Ley penal de los supuestos de hecho penalmente ilícitos. Por el contrario, es posible la incorporación al tipo de elementos normativos (STC 62/1982) y es conciliable con los postulados constitucionales la utilización legislativa y aplicación judicial de las llamadas Leyes penales en blanco (STC 122/1987), esto es, de normas penales incompletas en las que la conducta o la consecuencia jurídico-penal no se encuentre agotadoramente prevista en ellas, debiendo acudirse para su integración a otra norma distinta, siempre que se den los siguientes requisitos: que el reenvío normativo sea expreso y esté justificado en razón del bien jurídico protegido por la norma penal; que la Ley, además de señalar la pena, contenga el núcleo esencial de la prohibición y sea satisfecha la exigencia de certeza, o como señala la STC 122/1987; se dé la suficiente concreción para que la conducta calificada de delictiva quede suficientemente precisada con el complemento indispensable de la norma a la que la Ley penal se remite y resulte, de esta manera, salvaguardada la función de garantía del tipo con la posibilidad de conocimiento de la actuación penalmente conminada; pero es obvio que si bien falta la enumeración que efectuaba el Código de Comercio y que era aplicable en el ámbito penal por remisión de las normas correspondientes del Código de 1973, no menos cierto es que la no llevanza de contabilidad en la anterior legislación era una simple presunción (reprobable siempre e inaplicable en el ámbito penal) aunque constituía un supuesto autónomo para estimar culpable o fraudulenta la quiebra, como se deduce del número $1 .^{\circ}$ del artículo 889 del Código de Comercio. Pero todos los supuestos de los artículos citados de dicho cuerpo legal están incluidos también obviamente en el artículo 261 del NCP. Por consiguiente esta primera alegación debe ser rechazada.

Cuarto. Actuación en nombre de otro. Se alega también que el artículo 31 del NCP beneficia a los recurrentes sobre el artículo 15 bis del Código de 1973. Sin embargo no cabe aceptar tal alegación como jurídicamente fundada. La única diferencia sensible es la de la inclusión en el artículo 31 del NCP del supuesto del administrador de hecho, pero en cuanto al administrador de derecho tal figura sigue siendo igual a la de directivo u órgano de la persona jurídica a que se refería el citado artículo 15 bis. En consecuencia la adaptación de los recursos de Rafael y Luis S. C. deben ser asimismo desestimadas».

\section{Incumplimiento de deberes contables}

Puede interesar un comentario sobre irregularidades contables, incluso sobre ausencia de contabilidad, por parte de los sujetos activos de los procesos concursales, cuando se trate de empresarios mercantiles obligados a la llevanza contable, en la forma establecida por los arts. 25 
y siguientes del C. de C., y concordantes del TRLSA (arts. 171 y ss.), para destacar su despenalización en el Código Penal, pues la ausencia de contabilidad o la doble contabilidad no ha quedado tipificada en el nuevo Código Penal, salvo en sede tributaria ex art. 310 (delito contable).

Nieto Martín ${ }^{48}$ se pregunta si existe una laguna de punibilidad en la desaparición de la bancarrota documental y considera:

«... una de las novedades más importantes del art. 260 del CP en el marco del derecho comparado es la ausencia de mención expresa a las quiebras documentales... La ausencia de contabilidad... impide, una vez abierto el proceso concursal, la reconstrucción del patrimonio y de las operaciones y negocios realizada por el deudor comerciante... Si la contabilidad no existe, es irregular o está falseada resultará imposible reconstruir el pasivo y el activo del deudor y detectar aquellas operaciones que pueden ser revocadas o consideradas ineficaces por haberse hecho en fraude de acreedores...».

\section{Autoría y complicidad}

Sobre posible complicidad, Alonso ${ }^{49}$ recuerda que al igual que acontece respecto del tipo penal previsto en el art. 259, el art. 260, contrariamente a lo que sucedía en el antiguo Código (arts. 522 y 525), no contiene ninguna mención a los cómplices, y considera, remitiéndose al art. 28, además de al 29, que quien colabore con el deudor dolosamente para crear o agravar su situación de crisis económica, siempre que esta cooperación fuera necesaria (el que coopere a su ejecución con un acto sin el cual no se habría efectuado), será considerado como autor del delito. Si esta cooperación no es necesaria será considerado como cómplice, aunque no será sancionable la cooperación imprudente o culposa, sólo la dolosa. Para determinar cuándo hay dolo, y sin perjuicio del libre criterio del Juzgador, podrá acudirse como referente interpretativo al art. 166 de la Ley concursal, que se refiere a los cómplices de los concursos culpables.

Bueren $^{50}$ estudia la responsabilidad criminal de las personas jurídicas y el régimen aplicable a los cómplices:

«En relación a la responsabilidad de las personas jurídicas, el art. 31 CP establece que "el que actúe como administrador de hecho o de derecho de una persona jurídica, o en nombre o representación le-

\footnotetext{
48 Nieto Martín, Adán, op. cit., págs. 154 a 161.

49 Alonso, José M. ${ }^{\text {a }}$ op . cit., pág. 114.

50 Bueren Roncero, Carlos, op. cit., págs. 5-7.
} 
gal o voluntaria de otro, responderá personalmente, aunque no concurran en él las condiciones, cualidades o relaciones que la correspondiente figura de delito o falta requiera para poder ser sujeto activo del mismo, si tales circunstancias se dan en la entidad o persona en cuyo nombre o representación obre”. I.e., responden personalmente los administradores de hecho o de derecho de una persona jurídica, aunque no concurran en ellos las condiciones para resultar sujetos activos del delito, si la persona jurídica en cuyo nombre actúan sí reúne tales condiciones, y ello en virtud de la aplicación del principio según el cual societas delinquere non potest...

En el ámbito de las insolvencias punibles y, en particular, en el alzamiento de bienes, se configura como sujeto activo de la conducta descrita en el art. 257-1 CP, apartado $1 .^{\circ}$ el deudor, pudiendo tratarse tanto de persona física como de persona jurídica... Con relación a los delitos concursales, el art. 260-3 CP menciona éstos "y a los delitos singulares relacionados con él, cometidos por el deudor o persona que haya actuado en su nombre”. La interpretación literal de este precepto, según J.M. Alonso Puig, atentaría contra el principio de culpabilidad y contra la presunción de inocencia, por lo que sostiene este autor que "sólo en el supuesto de que el deudor (en este caso, el Consejo de Administración) conociera o consintiera los actos realizados por la persona que actúa en su nombre (director financiero) cabrá imputar a aquél el delito de insolvencia punible a que se refiere ese artículo" y, en el seno de aquél, sólo a aquéllos que lo hubieran conocido y consentido.

Siguiendo con el art. 258 CP, éste utiliza, para referirse al sujeto activo, la expresión "los responsables", y cabe considerar como posibles sujetos activos de la conducta aquí descrita tanto a los autores como a los partícipes e, incluso, a los responsables civiles subsidiarios, dada la amplitud de la formulación del precepto (Quintero Olivares).

Pasando ya al examen de la complicidad en el seno de los delitos concursales, el art. 259 castiga la vulneración de la preferencia de pago, es decir, la conducta del deudor insolvente que, tras ser declarado en concurso, realiza un acto dispositivo para pagar una deuda preexistente, posponiendo al resto de los acreedores... En estos casos, serán cómplices del deudor insolvente aquellos acreedores que se pongan de acuerdo con él para obtener el pago de sus créditos con preferencia a los demás y sin la autorización de los órganos rectores o de los administradores del proceso. Es decir, se trata de supuestos en los que se atenta contra la par conditio creditorum.

Continuando con el art. 260 CP, que regula el tipo básico en los delitos concursales, éste, al igual que el artículo precedente y a diferencia del CP de 1973, no contiene referencia alguna a los cómplices, por lo que tendremos que remitirnos a lo dispuesto en los arts. 28 y 29 CP. Así, será autor del delito el que hubiese cooperado a la creación o agravación de la insolvencia del deudor con un acto sin el cual no se 
habrá ésta logrado, es decir, el que hubiera contribuido a la misma en calidad de cooperador necesario; y será simplemente cómplice del delito aquél cuya cooperación no hubiese sido necesaria.

Finalmente, el art. 261 CP introduce la estafa procesal contable, cuyo destinatario no es sólo el deudor, sino también aquellas personas cuya colaboración resulta imprescindible para conseguir la finalidad perseguida con tal conducta: contables, asesores fiscales e, incluso, los interventores [administradores concursales]».

Sobre responsabilidad penal de los órganos auxiliares del concurso he realizado un brevísimo comentario al hilo del art. 261, pero habrá de añadirse la posibilidad de que sean reos del delito contra la Administración de Justicia por falso testimonio, tipificado en los arts. 458 a 462 CP.

\section{Calificación civil y proceso penal}

Considero que la calificación civil del nuevo concurso de acreedores mantiene su eficacia, como fuente de información sobre posibles ilícitos penales, aunque no vinculará a los jueces y tribunales del orden jurisdiccional penal (art. 163.2), y cuya incoación no provocará la suspensión de la tramitación del concurso (art. 189.1).

El tratamiento de la insolvencia concursal punible ex arts. 259 a 261, dada su mención expresa al concurso de acreedores, se ha desvinculado de la regulación extrapenal civil o mercantil. No obstante, las Diligencias Previas que se instruyan, en su caso, pueden recibir el apoyo fáctico del procedimiento concursal, particularmente de la sección sexta del concurso sobre calificación, con la colaboración de la administración concursal. En general, los auditores de cuentas y otros peritos contables (economistas y profesores mercantiles), en estos procesos penales, pueden colaborar con su dictamen en las pruebas pertinentes.

Bueren $^{51}$ comenta que desde diversos sectores se ha apuntado que separar por completo ambos órdenes (civil y penal) implica el riesgo de que el órgano decisor en el proceso penal posea un imperfecto conocimiento de la conducta de la sociedad insolvente, y que al permitir a cualquier acreedor que acuda al procedimiento penal, con la equivocada creencia de ser la vía para resarcirse del perjuicio que se le ha inferido, se provoca la tramitación de dos procesos sobre la misma realidad, pero sin la intervención en el proceso penal de los órganos concursales de administración nombrados en el proceso civil, cuando dichos órganos son los que mejor pueden averiguar la existencia o inexistencia de

\footnotetext{
51 Bueren Roncero, Carlos, op. cit., pág. 14.
} 
dolo en la conducta de la sociedad insolvente, al conocerla desde su interior, por lo que la colaboración de los mismos con el juez penal sería conveniente en aras de unas decisiones mejor fundadas y, por tanto, en aras de una mayor seguridad jurídica.

Sobre la determinación de las conductas típicas ex art. 260 CP, aunque lo considero aplicable a los demás delitos de insolvencias punibles, Nieto Martín ${ }^{52}$ considera conveniente emprender un viaje de regreso y seguir considerando significativos a los efectos de interpretar el delito de quiebra los comportamientos de bancarrota fraudulenta que se contienen en el Código de Comercio (arts. 890 y 891, derogados)».

\section{El Ministerio Fiscal}

Es evidente cierto protagonismo de los órganos auxiliares del concurso de acreedores, para el descubrimiento, acreditación y denuncia de los delitos perseguidos en el Capítulo VII del CP sobre insolvencias punibles, pero lo relevante es la intervención del Ministerio Fiscal, como titular de la acción penal, para la persecución de infracciones punibles, dada su condición de parte, en la pieza sexta del nuevo concurso (art. 184.153). Efectivamente, la alta misión constitucional del Ministerio Fiscal, en la defensa incondicionada de la legalidad y el interés público, permite asignar al Fiscal funciones del máximo relieve en el plano procesal mercantil, con la finalidad de garantizar el crédito, en general, y en aras del interés público, además de la que le es propia en su proyección punible, así como por imperativo del dictamen que debe emitir sobre la clase de concurso en la Ley concursal (art. 169), en la sección sexta, a la que se limita su intervención como parte, según la exposición de motivos. Sin embargo, no será infrecuente, dada la complejidad del art. 55 de la Ley Concursal, que deba intervenir en los supuestos de que el Juzgado de lo Mercantil plantease conflicto de jurisdicción a la Administración pública, según la Ley Orgánica 2/1987, de 18 de mayo ${ }^{54}$. Tam-

\footnotetext{
52 NiETo Martín, Adán, págs. 111-154.

53 «En todas las secciones serán reconocidos como parte, sin necesidad de comparecencia en forma, el deudor y los administradores concursales. El Fondo de Garantía Salarial deberá ser citado como parte cuando del proceso pudiera derivarse su responsabilidad para el abono de salarios o indemnizaciones de los trabajadores. En la sección sexta será parte, además, el Ministerio Fiscal».

54 Artículo nueve. «1. El juez o tribunal que, por su propia iniciativa o a instancia de parte, considere de su jurisdicción un asunto de que está conociendo un órgano administrativo, deberá, antes de requerirle de inhibición, solicitar el informe del ministerio fiscal, que habrá de evacuarlo en plazo de cinco días».
} 
bién el art. 12.155 dispone que el Ministerio Fiscal sea oído en cuestiones de competencia territorial. Además, en actuaciones por delitos contra el patrimonio y contra el orden socioeconómico (Título XIII del Libro II del Código Penal), el art. $4^{56}$ de dicha Ley Concursal encomienda al Ministerio Fiscal determinadas iniciativas relacionadas con la insolvencia de algún presunto responsable penal y el procedimiento concursal. Por último, el art. 41 de la Ley Concursal, relativo a los efectos del concurso sobre derechos fundamentales del deudor, se remite a la Ley Orgánica para la Reforma Concursal ${ }^{57}$, cuyo artículo primero ${ }^{58}$ autoriza la

55 «La interposición de declinatoria, en la que el promotor estará obligado a indicar cuál es el órgano competente para conocer el concurso, no suspenderá el procedimiento concursal. En ningún caso se pronunciará el juez sobre la oposición del concursado sin que previa audiencia del Ministerio Fiscal haya resuelto la cuestión de competencia planteada...»

56 «Cuando en actuaciones por delitos contra el patrimonio y contra el orden socioeconómico se pongan de manifiesto indicios de estado de insolvencia de algún presunto responsable penal y de la existencia de una pluralidad de acreedores, el Ministerio Fiscal instará del juez que esté conociendo de la causa la comunicación de los hechos al juez de lo mercantil con competencia territorial para conocer del concurso del deudor, a los efectos pertinentes, por si respecto de éste se encontrase en tramitación un procedimiento concursal. Asimismo, instará el Ministerio Fiscal del juez que conozca de la causa la comunicación de aquellos hechos a los acreedores cuya identidad resulte de las actuaciones penales en curso, a fin de que, en su caso, puedan solicitar la declaración de concurso o ejercitar las acciones que les correspondan».

57 Artículo primero de la LEY ORGÁNICA 8/2003, de 9 de julio, para la Reforma Concursal, por la que se modifica la Ley Orgánica 6/1985, de 1 de julio, del Poder Judicial (BOE núm. 164, de 10 julio 2003).

58 «1. Desde la admisión a trámite de la solicitud de declaración de concurso necesario, a instancias del legitimado para instarlo, o desde la declaración de concurso, de oficio o a instancia de cualquier interesado, y tanto en los casos de suspensión como en los de intervención de las facultades de administración y disposición del deudor sobre su patrimonio, el juez podrá acordar en cualquier estado del procedimiento las siguientes medidas: $1 .{ }^{a}$ La intervención de las comunicaciones del deudor, con garantía del secreto de los contenidos que sean ajenos al interés del concurso. 2. ${ }^{a}$ El deber de residencia del deudor persona natural en la población de su domicilio. Si el deudor incumpliera este deber o existieran razones fundadas para temer que pudiera incumplirlo, el juez podrá adoptar las medidas que considere necesarias, incluido el arresto domiciliario. $3 .^{a}$ La entrada en el domicilio del deudor y su registro. 2. Si se tratare del concurso de una persona jurídica, las medidas previstas en el apartado anterior podrán acordarse también respecto de todos o alguno de sus administradores o liquidadores, tanto de quienes lo sean en el momento de la solicitud de declaración de concurso como de los que lo hubieran sido dentro de los dos años anteriores. 3. La adopción de cualquiera de las medidas descritas en el apartado 1 de este artículo se acordará previa audiencia del Ministerio Fiscal y mediante decisión judicial motivada, conforme a los siguientes criterios: a) La idoneidad de la medida en relación con el estado del procedimiento de concurso; b) El resultado u objetivo perseguido, que se expondrá de manera concreta; c) La proporcionalidad entre el alcance de cada medida y el resultado u objetivo perseguido; d) La duración de la medida, con fijación del 
intervención de las comunicaciones postales y quizá en las telefónicas, así como el supuesto de registro en el domicilio del deudor, sus administradores o liquidadores y de los que lo hubieran sido dentro de los dos años anteriores a la fecha de declaración de concurso, en las que resultará imperativa la intervención del Ministerio Fiscal.

La Ley 10/1995, de 24 de abril, crea la Fiscalía Especial para la Represión de los Delitos Económicos relacionados con la Corrupción, a la que se faculta, por modificación de la Ley 50/1981, para intervenir

«directamente en procesos penales de especial trascendencia, apreciada por el Fiscal General del Estado, en relación a: a) Delitos contra Hacienda Pública, contrabando, y en materia de control de cambios. b) Delitos de prevaricación. c) Delitos de abuso o uso indebido de información privilegiada. d) Malversación de caudales públicos. e) Fraudes y exacciones ilegales. $f$ ) Delitos de tráfico de influencias. $g$ ) Delitos de cohecho. h) Negociación prohibida a los funcionarios. i) Delitos comprendidos en los capítulos IV y V del Título XIII del Libro II del Código Penal. j) Delitos conexos con los anteriores».

\section{Concurso de delitos}

Un comentario sobre el concurso de delitos, para expresar la inquietud sobre la compatibilidad del delito de insolvencia (art. 260) con alguno de los delitos societarios y, particularmente, con los tipificados en los arts. 290 y 295 del Código Penal, que sancionan la falsedad en las cuentas anuales u otros documentos y la administración desleal del patrimonio ajeno, es decir, castigan el incumplimiento doloso del macroprincipio contable de la imagen fiel y la disposición fraudulenta de bienes o asunción de obligaciones, en perjuicio de terceros vinculados con la entidad que administran. Al respecto, viene a colación lo dis-

tiempo máximo de vigencia, que no podrá exceder del estrictamente necesario para asegurar el resultado u objetivo perseguido, sin perjuicio de que, de persistir los motivos que justificaron la medida, el juez acuerde su prórroga con los mismos requisitos que su adopción. Durante el tiempo de vigencia de la medida, el juez podrá acordar en cualquier momento su atenuación o cese. 4. La intervención de las comunicaciones telefónicas deberá realizarse conforme a lo previsto en la Ley de Enjuiciamiento Criminal. 5. La autorización judicial de entrada y registro en el domicilio del deudor o de las personas a las que se refiere el apartado 2 de este artículo, cuando nieguen su consentimiento, habrá de basarse en indicios racionales de existencia de documentos de interés para el procedimiento concursal, no aportados, o en la necesidad de esta medida para la adopción de cualquier otra procedente. 6. Las decisiones judiciales estimatorias podrán ser recurridas en apelación por el deudor en el plazo de cinco días, sin efectos suspensivos, ante la Audiencia Provincial. Este recurso tendrá tramitación preferente». 
puesto en el art. 260.3 del Código Penal: «Este delito [el de quiebra] y los delitos singulares relacionados con él, cometidos por el deudor o persona que haya actuado en su nombre, podrán perseguirse...». Puede ponerse en relación con la doctrina sobre delitos autónomos, en la regulación anterior del delito de quiebra y concurso, y la responsabilidad de los órganos auxiliares de los procedimientos concursales en su descubrimiento y denuncia, con apoyo fáctico en la contabilidad. No debe olvidarse el denominado delito contable, ex art. 310 del CP, en sede tributaria.

Sobre el concurso de leyes, Rodríguez $\operatorname{Ramos}^{59}$ expresa fundada crítica sobre el art. 8 del CP, que ofrece una serie de criterios imperativos para solucionar los llamados concursos impropios, aparentes, de leyes o normas, con causa en un doble y grave error: a) por no haber reducido su contenido al principio de especialidad; y, b) por mantener el contenido del derogado art. 68 como regla cuarta.

\section{Prescripción}

Por último, una brevísima referencia a la prescripción, para concretar que los delitos de insolvencias punibles, previstos en los arts. 257 a 259 , por tratarse de delitos graves, con penas de prisión que pueden superar los tres años (de uno a cuatro), prescriben a los cinco años. El delito ex art. 260, que puede ser sancionado con penas de prisión superiores a cinco años (de dos a seis), prescribirá a los diez años. Y el delito castigado en el art. 261, que puede ser penado de uno a dos años, prescribirá a los tres años. El cómputo de la prescripción se inicia el día que se haya cometido la infracción punible, pero sobre cuándo se entiende cometida la infracción, la doctrina científica se encuentra dividida, según se defienda «la teoría de la acción» o «la teoría del resultado».

La STS (Sala Segunda), de 15.12.1997, en el Fundamento de Derecho Cuarto, resuelve:

«Entiende que por tratarse de un delito menos grave, la prescripción se produce a los tres años y la propia recurrente denunció la paralización del procedimiento de 13 de diciembre de 1989 a 21 de enero de 1993. Esta Sala no puede compartir los argumentos de la parte recurrente y sí acepta, por el contrario, integramente, los utilizados por

59 RoDRíGUEZ RAmOS, Luis, «Error reduplicado en la regulación del concurso de leyes (exégesis crítica del art. 8 del Código Penal)». Actualidad Jurídica Aranzadi, núm. 330, año VIII, 19 de febrero de 1998, págs. 1-4. 
el Tribunal de instancia en el fundamento jurídico primero de la sentencia.

A solicitud de la defensa de los acusados, por ser más favorable el Código Penal de 1995, se elevaron a definitivas las calificaciones de conformidad con esta normativa. En cuanto a la invocada prescripción del art. 131.1 y 3, hay que tener en cuenta que el delito de quiebra se encuentra sancionado con pena de prisión de dos a seis años y multa de ocho a veinticuatro meses y el precepto citado como infringido, el art. 131, recoge la prescripción a los diez años cuando la pena señala sea de más de cinco y menos de diez años. Con tal claridad el motivo tiene que perecer, habida cuenta además de los argumentos de la Sala de instancia que este Tribunal ratifica para evitar repeticiones».

Para finalizar, presento mis disculpas por el intrusismo en materia penal y en otras, que puede justificarse, con benevolencia, por la intención de colaborar con mis compañeros de oficio, así como para que abogados y otros operadores jurídicos conozcan las limitaciones que padecemos algunos miembros de la profesión contable. 